Marquette University

e-Publications@Marquette

10-2007

\title{
Benzimidazolium Surfactants for Modification of Clays for Use with Styrenic Polymers
}

\author{
Marius C. Costache \\ Marquette University \\ Matthew Heidecker \\ Pennsylvania State University - Main Campus \\ Evangelos Manias \\ Pennsylvania State University - Main Campus \\ Rakesh K. Gupta \\ West Virginia University \\ Charles A. Wilkie \\ Marquette University, charles.wilkie@marquette.edu
}

Follow this and additional works at: https://epublications.marquette.edu/chem_fac

Part of the Chemistry Commons

\section{Recommended Citation}

Costache, Marius C.; Heidecker, Matthew; Manias, Evangelos; Gupta, Rakesh K.; and Wilkie, Charles A., "Benzimidazolium Surfactants for Modification of Clays for Use with Styrenic Polymers" (2007).

Chemistry Faculty Research and Publications. 37.

https://epublications.marquette.edu/chem_fac/37 


\title{
Benzimidazolium Surfactants for the Modification of Clays for use with Styrenic Polymers
}

\author{
Marius C. Costache \\ Deparment of Chemistry, Marquette University \\ Milwaukee, WI
}

Matthew J. Heidecker

Department of Materials Science and Engineering, Penn State

University

University Park, PA

E. Manias

Department of Materials Science and Engineering, Penn State

University

University Park, PA

Rakesh K. Gupta

Department of Chemical Engineering, West Virginia University

Morgantown, WV

Charles A. Wilkie

Deparment of Chemistry, Marquette University

Milwaukee, WI 
NOT THE PUBLISHED VERSION; this is the author's final, peer-reviewed manuscript. The published version may be accessed by following the link in the citation at the bottom of the page.

\begin{abstract}
:
Nanocomposites of polystyrene (PS), acrylonitrile-butadiene-styrene copolymer (ABS) and high impact polystyrene (HIPS) were prepared with two new homologous benzimidazolium surfactants used as organic modifications for the clays. The morphology of the polymer/clay hybrids was evaluated by powder X-ray diffraction (XRD) and transmission electron microscopy (TEM), showing good overall dispersion of the clay. The thermal stability of the polymer/clay nanocomposites was enhanced, as evaluated by thermogravimetric analysis. From cone calorimetric measurements, the peak heat release rate of the nanocomposites was decreased by about the same amount as seen for other organically-modified, commercially available clays.
\end{abstract}

Keywords: Polystyrene, Nanocomposites, Fire retardancy, Benzimidazolium surfactant.

\title{
1. Introduction
}

Even though their preparation was described [1] in the 1960s, the field of polymer/layer silicate nanocomposites (PLSN) has only been actively pursued in the last decade or so, mostly because such materials can facilitate concurrent enhancements in mechanical, barrier, thermal and flammability properties [2], [3], [4], [5], [6] and [7]. However, in order to take full advantage of all these benefits, the surfactant and, subsequently, the nanocomposite, must "survive" the fabrication process or, in other words, the temperature or the extended residence time under shear must not lead to material degradation. If the processing or the synthesis temperature of the polymer exceeds the maximum temperature at which the surfactant is stable, then the latter will undergo degradation, with negative effects both on the appearance of the material and its properties [8], [9], [10], [11], [12], [13] and [14]. The most common, and commercially available, surfactants are quaternary ammonium salts, that when present as cations in montmorillonite, typically begin degradation at $200{ }^{\circ} \mathrm{C}$ or below [15]. For some polymers this is acceptable, but for engineering polymers, such as poly(ethylene terephthalate), polyamide-6, polyamide-6,6 and polycarbonate, more thermally stable clays are required in order to prepare nanocomposites with superior properties by melt blending. Because of this need for enhanced thermal stability of the organically-modified clays, a series of new surfactants have been developed; representative examples of such

Polymer Degradation and Stability, Vol. 92, No. 10 (October 2007): pg. 1753-1762. DOI. This article is @ Elsevier and permission has been granted for this version to appear in e-Publications@Marquette. Elsevier does not grant permission for this article to be further copied/distributed or hosted elsewhere without the express permission from Elsevier. 
compounds are imidazolium [16] and phosphonium halides [17] and [18]. Other, newly developed clays, such as oligomeric [19] or quinolinium [20], have been used for other polymeric systems and present promising thermal stability, and may be suitable for hightemperature polymers [21].

Benzimidazole can be viewed as a homologue of imidazole, therefore it is easy to envision that once one of the nitrogens is quaternized, it may be possible to produce a surfactant with similar, or superior, thermal properties to imidazolium salts. Consequently, the objective of this study is to prepare benzimidazolium surfactants, use them to modify montmorillonite and then compare these organicallymodified clays with others for their ability to disperse in polymers and enhance thermal stability.

\section{Experimental}

\subsection{Materials}

Polystyrene (PS) with an average $M_{\mathrm{w}} \sim 230,000$, average $M_{\mathrm{n}} \sim 140,000$, softening point $107^{\circ} \mathrm{C}$ (Vicat, ASTM D 1525) and melt index $7.5 \mathrm{~g} / 10 \mathrm{~min}$ (ASTM D 1238, $200^{\circ} \mathrm{C} / 5 \mathrm{~kg}$ ), tetrahydrofuran (98\%), benzimidazole (98\%), 1-bromohexadecane (97\%), 2methylbenzimidazole (98\%), were purchased from Aldrich Chemical Co., Inc. The ABS used was Magnum 275, melt flow index $230^{\circ} \mathrm{C} / 3.8 \mathrm{~kg}, 2.6 \mathrm{~g} / 10 \mathrm{~min}, M_{\mathrm{w}}: 160,000$ and the HIPS was Styron 438 , melt flow index $200{ }^{\circ} \mathrm{C} / 5 \mathrm{~kg}, 4.5 \mathrm{~g} / 10 \mathrm{~min} ; M_{\mathrm{w}}: 300,000$, both of which were provided by Dow Chemical Company. Sodium montmorillonite was kindly provided by Southern Clay Products, Inc.

\subsection{Instrumentation}

Dispersion of silicates in the polymer matrix was observed by powder X-ray diffraction measurements (XRD) performed as continuous scan at $0.6 \% \mathrm{~min}$ using a Rigaku powder diffractometer with a $\mathrm{Cu}$ Ka source $(\lambda=1.54 \AA)$; generator tension was $50 \mathrm{kV}$ at $20 \mathrm{~mA}$. The polymer/MB33 samples for TEM were microtomed at room temperature in a RMR Powertome XL Ultramicrotome using a diamond knife and the sections were transferred to a 800-mesh copper grid. For ABS and HIPS samples, the thin sections were stained with osmium

Polymer Degradation and Stability, Vol. 92, No. 10 (October 2007): pg. 1753-1762. DOI. This article is @ Elsevier and permission has been granted for this version to appear in e-Publications@Marquette. Elsevier does not grant permission for this article to be further copied/distributed or hosted elsewhere without the express permission from Elsevier. 
tetraoxide vapors (freshly prepared) before examining in a JEOL 100CX transmission electron microscope operated at accelerating voltage of $100 \mathrm{kV}$. TEM images of the polymer/MB32 samples were obtained at $80 \mathrm{kV}$ with a JEOL 1200 EXII electron microscope equipped with a Tietz F224 digital camera. Ultrathin sections (70-100 nm) of the nanocomposites were cut from a plaque using a microtome (Leica Ultracut UCT) equipped with a diamond knife. The sections were transferred to carbon-coated copper grids (200 mesh). No heavy metal staining of sections prior to imaging was necessary, since the contrast between the layered silicate and the polymer matrix was sufficient.

Thermogravimetric analysis (TGA) was performed on a SDT 2960 simultaneous DTA-TGA unit from TA Instruments, under a constant nitrogen flow of $40 \mathrm{~mL} / \mathrm{min}$. The experiments were performed at a temperature ramping of $20^{\circ} \mathrm{C} / \mathrm{min}$ from 100 to $600{ }^{\circ} \mathrm{C}$. All samples were run in triplicate and showed good reproducibility; temperatures are considered accurate to $\pm 4{ }^{\circ} \mathrm{C}$, while the char remaining at $600{ }^{\circ} \mathrm{C}$ is considered to be accurate to $\pm 3 \%$.

Cone calorimeter measurements were performed at an incident flux of $35 \mathrm{~kW} / \mathrm{m}^{2}$, using an Atlas Cone 2 instrument with a truncated cone-shaped heater, according to ASTM E-1354. Exhaust flow rate was $24 \mathrm{~L} / \mathrm{s}$ and the spark was continued until the sample ignited. The specimens for cone calorimetry were prepared by the compression molding of the sample (about $30 \mathrm{~g}$ ) into $3 \times 100 \times 100 \mathrm{~mm}$ square plaques. Typical results from cone calorimetry are reproducible to within $\pm 10 \%$. The reported results are the average of three determinations.

\subsection{Preparation of surfactants}

\subsubsection{1-Hexadecyl-1H-benzimidazole (1)}

In a round bottom flask equipped with condenser, $120 \mathrm{~mL}$ THF was stirred at $60{ }^{\circ} \mathrm{C}$ for 20 min with $12 \mathrm{~g}$ (300 mmol) $\mathrm{NaOH}$ powder. To this suspension, $8.2 \mathrm{~g}$ (70 mmol) of $1 \mathrm{H}$-benzimidazole was added in one portion and then the mixture was refluxed for $1 \mathrm{~h}$. Subsequently, $24 \mathrm{~g}$ (77 mmol) of 1-bromohexadecane was added and the mixture was refluxed for $3 \mathrm{~h}$. The solution was cooled to room temperature and about $20 \mathrm{~mL}$ of water was added. The aqueous layer was removed and

Polymer Degradation and Stability, Vol. 92, No. 10 (October 2007): pg. 1753-1762. DOI. This article is (C) Elsevier and permission has been granted for this version to appear in e-Publications@Marquette. Elsevier does not grant permission for this article to be further copied/distributed or hosted elsewhere without the express permission from Elsevier. 
extracted three times with dichloromethane. The combined organic layers were added to the THF solution, dried over anhydrous magnesium sulfate and the solvent was removed under vacuum, yielding $23.9 \mathrm{~g}(67.2 \mathrm{mmol})$ product (96\% yield). ${ }^{1} \mathrm{H} \mathrm{NMR}\left(\mathrm{CDCl}_{3}\right) \delta$ (ppm): $7.88(\mathrm{~s}, 1 \mathrm{H}, \mathrm{N}-\mathrm{CH}-\mathrm{N}), 7.81(\mathrm{~m}, 1 \mathrm{H}, A r), 7.39(\mathrm{~m}, 1 \mathrm{H}, A r)$, $7.281(\mathrm{~m}, 2 \mathrm{H}, A r), 4.15\left(\mathrm{t}, \mathrm{J}=7.3 \mathrm{~Hz}, 2 \mathrm{H}, \mathrm{N}-\mathrm{CH}_{2}\right), 1.87$ (pent, $\left.\mathrm{J}=7.5 \mathrm{~Hz}, 2 \mathrm{H}, \mathrm{N}-\mathrm{CH}_{2}-\mathrm{CH}_{2}\right), 1.26\left(\mathrm{~m}, 26 \mathrm{H}, \mathrm{CH}_{2(13)}\right), 0.88(\mathrm{t}$, $J=7.5 \mathrm{~Hz}, 3 \mathrm{H}, \mathrm{CH}_{3}$ ).

\subsection{2. (BZ32) 1,3-Dihexadecyl-3H-benzimidazol-1-ium bromide} (2)

In a three-neck round bottom flask equipped with condenser, $23.9 \mathrm{~g}(67.2 \mathrm{mmol}) 1$-hexadecyl- $1 H$-benzimidazole, was dissolved in $80 \mathrm{~mL}$ THF and $24 \mathrm{~g}$ ( $77 \mathrm{mmol})$ of 1-bromohexadecane was added. The solution was refluxed for $48 \mathrm{~h}$, then, after cooling and filtration, the crude crystals were washed with petroleum ether previously cooled in an ice bath to yield the pure product $(41.3 \mathrm{~g}, 62.5 \mathrm{mmol}, 93 \%$ yield). ${ }^{1} \mathrm{H}$ NMR $\left(\mathrm{CDCl}_{3}\right) \delta(\mathrm{ppm}): 11.462(\mathrm{~s}, 1 \mathrm{H}, \mathrm{N}-\mathrm{CH}-\mathrm{N}), 7.680(\mathrm{~m}$, $4 \mathrm{H}, A r), 4.64\left(\mathrm{t}, \mathrm{J}=7.3 \mathrm{~Hz}, 4 \mathrm{H}, \mathrm{N}-\mathrm{CH}_{2}\right), 2.05$ (pent, $\mathrm{J}=7.5 \mathrm{~Hz}, 4 \mathrm{H}$, $\left.\mathrm{N}-\mathrm{CH}_{2}-\mathrm{CH}_{2}\right), 1.24\left(\mathrm{~m}, 52 \mathrm{H}, \mathrm{CH}_{2(13)}\right), 0.87\left(\mathrm{t}, \mathrm{J}=7.5 \mathrm{~Hz}, 6 \mathrm{H}, \mathrm{CH}_{3}\right)$.

\subsubsection{2-Methyl-1-hexadecyl-1H-benzimidazole (3)}

Compound 3 was prepared following the same procedure as for (1). ${ }^{1} \mathrm{H} \mathrm{NMR}\left(\mathrm{CDCl}_{3}\right) \delta(\mathrm{ppm}): 7.67(\mathrm{~s}, 1 \mathrm{H}, A r), 7.22(\mathrm{~m}, 3 \mathrm{H}, A r), 3.40$ $\left(\mathrm{t}, \mathrm{J}=7.3 \mathrm{~Hz}, 2 \mathrm{H}, \mathrm{N}-\mathrm{CH}_{2}\right), 2.60\left(\mathrm{~s}, 3 \mathrm{H}, \mathrm{N}-\mathrm{CH}_{3}-\mathrm{N}\right), 1.84$ (pent, $\left.\mathrm{J}=7.5 \mathrm{~Hz}, 2 \mathrm{H}, \mathrm{N}-\mathrm{CH}_{2}-\mathrm{CH}_{2}\right), 1.25\left(\mathrm{~m}, 26 \mathrm{H}, \mathrm{CH}_{2(13)}\right), 0.87(\mathrm{t}$, $J=7.3 \mathrm{~Hz}, 3 \mathrm{H}, \mathrm{CH}_{3}$ ).

2.3.4. (BZ33) 2-Methyl-1,3-dihexadecyl-3H-benzimidazol-1-ium bromide (4)

Compound 4 was prepared following the same procedure as for (2). ${ }^{1} \mathrm{H} \mathrm{NMR}\left(\mathrm{CDCl}_{3}\right) \delta(\mathrm{ppm}): 7.64(\mathrm{~m}, 2 \mathrm{H}, \mathrm{Ar}), 7.57(\mathrm{~m}, 2 \mathrm{H}, \mathrm{Ar})$, $4.56\left(\mathrm{t}, \mathrm{J}=7.3 \mathrm{~Hz}, 4 \mathrm{H}, \mathrm{N}-\mathrm{CH}_{2}\right), 3.23\left(\mathrm{~s}, 3 \mathrm{H}, \mathrm{N}-\mathrm{CH}_{3}-\mathrm{N}\right), 1.87$ (pent, $\left.\mathrm{J}=7.5 \mathrm{~Hz}, 4 \mathrm{H}, \mathrm{N}-\mathrm{CH}_{2}-\mathrm{CH}_{2}\right), 1.27\left(\mathrm{~m}, 52 \mathrm{H}, \mathrm{CH}_{2(13)}\right), 0.83(\mathrm{t}$, $\left.J=7.3 \mathrm{~Hz}, 6 \mathrm{H}, \mathrm{CH}_{3}\right)$.

Polymer Degradation and Stability, Vol. 92, No. 10 (October 2007): pg. 1753-1762. DOI. This article is (C) Elsevier and permission has been granted for this version to appear in e-Publications@Marquette. Elsevier does not grant permission for this article to be further copied/distributed or hosted elsewhere without the express permission from Elsevier. 


\subsection{Preparation of polymer-clay nanocomposites}

The modified clays were prepared as follows: $50 \mathrm{~g}$ of sodium montmorillonite were dispersed overnight in $1800 \mathrm{~mL}$ of $3: 1$ ethanol/water ( $\mathrm{v} / \mathrm{v}$ ) under vigorous stirring, using a magnetic stirrer. The suspension was placed on a water bath and heated to $60{ }^{\circ} \mathrm{C}$, after which a mixture of $60 \mathrm{mmol}$ surfactant (20\% excess surfactant, based on the cation exchange capacity of the clay) in $200 \mathrm{~mL}$ ethanol was added in small portions over $1 \mathrm{~h}$. The stirring was continued for $24 \mathrm{~h}$ at $60^{\circ} \mathrm{C}$. The modified clay was then filtered and washed first with the ethanol/water solution and then with distilled water, until the silver nitrate test was negative. The montmorillonite clay (MMT) modified with 1,3-dihexadecyl-3H-benzimidazol-1-ium (BZ32) was named MB32 and the montmorillonite modified with 2-methyl-1,3-dihexadecyl-3Hbenzimidazol-1-ium (BZ33) was named MB33. All nanocomposites were prepared by melt blending in a Brabender Plasticorder, at $190{ }^{\circ} \mathrm{C}$ and $60 \mathrm{rpm}$ for $15 \mathrm{~min}$ at a clay loading of $3 \%$ modified clay.

\section{Results and discussion}

\subsection{Morphology of polymer-clay nanocomposites}

The enhanced thermal stability of imidazolium surfactants as compared with the alkylammonium halides has been reported to be due to the delocalization of the positive charge over the imidazole ring [22] and [23]. Similarly, if the charge delocalization is increased by fusing a benzene ring to imidazole (as in the case of benzimidazole), one might expect further enhanced thermal stability. Additionally, the substitution of a methyl group at the methine position of the imidazolium was also found to improve the stability of the surfactant [16]. Therefore, for this study, two benzimidazolium halides (BZ32 and BZ33) have been prepared and the effect of methyl substitution at the 2-position of benzimidazolium on the thermal properties and dispersion of the clay were evaluated. The structures of the surfactants are shown in Scheme 1; the only difference between these is that BZ33 has a methyl group at the position between the two nitrogens while BZ32 does not.

The $d$-spacing of MB33 organo-clay is $2.9 \mathrm{~nm}$, as seen from Fig. 1. Upon nanocomposite formation, the 001 basal $d$-spacing

Polymer Degradation and Stability, Vol. 92, No. 10 (October 2007): pg. 1753-1762. DOI. This article is (C) Elsevier and permission has been granted for this version to appear in e-Publications@Marquette. Elsevier does not grant permission for this article to be further copied/distributed or hosted elsewhere without the express permission from Elsevier. 
appears to increase for all of the polymers studied (from 2.9 to $3.7 \mathrm{~nm}$ ). The increased basal spacing upon nanocomposite formation could be an indication of the intercalated nanocomposite structures suggesting that the thermodynamics of dispersion are favorable between the organo-clay and polymers, or it could simply be an experimental artifact, since there is only a small change in the $2 \theta$ value of the samples.

Similar intercalated morphologies have been observed for hexadecyl-2,3-dimethylimidazolium montmorillonite and PS [16], and hexadecyl-imidazolium and dihexadecyl-imidazolium montmorillonite and syndiotactic polystyrene (SPS) [24]. The reported basal $d$-spacings for those nanocomposites were $3.2 \mathrm{~nm}$ for PS [16] and 3-3.5 nm for sPS [24]. The slightly larger values obtained here for benzimidazolium can be attributed to the presence of a second tail on the surfactant, as opposed to only one tail on imidazolium [16] and [24], and to changes in the alkyl conformations due to the existence of the additional benzyl ring.

The TEM images support the initial observations from the XRD patterns. When the MB33 clay is added to the PS matrix (Fig. 2), a well-dispersed intercalated structure is developed. The majority of the clay tactoids are small (5-700 nm in length and 3-500 nm wide) but a few larger agglomerates are present. The small tactoids (Fig. 2, high magnification) typically consist of 5-8 stacked clay layers with some individual layers also visible. For ABS and HIPS, the rubber phase is also clearly observed and, possibly, crazing in the styrenics portion can be seen in all systems; these are identified in the images. As shown in Fig. 3 and Fig. 4, for both copolymers, the clay is uniformly distributed (low magnification images) throughout the PS phase. In the high magnification micrographs, the stacked clay layers are visible, again verifying the intercalated morphology manifested in the XRD patterns.

As can be seen from the Fig. 5, the organically-modified clay MB32 also displayed a significantly expanded $d$-spacing as compared to the unmodified Na-MMT (2.9 nm vs. $1.2 \mathrm{~nm}$ ). However, upon melt blending with PS, ABS and HIPS, the interlayer distance remained largely unchanged, behavior that may be attributed to an immiscible nanocomposite. However, direct observation of the nanocomposite morphology by TEM imaging ( Fig. 6, Fig. 7 and Fig. 8) shows that in all three polymer/clay nanocomposite systems, there exists polymer

Polymer Degradation and Stability, Vol. 92, No. 10 (October 2007): pg. 1753-1762. DOI. This article is @ Elsevier and permission has been granted for this version to appear in e-Publications@Marquette. Elsevier does not grant permission for this article to be further copied/distributed or hosted elsewhere without the express permission from Elsevier. 
penetration into the clay galleries and formation of intercalated nanocomposites. In the case of the PS system ( Fig. 6) relatively large clay tactoids (with sizes ranging from a few hundred nanometers to a few microns) are uniformly distributed in the polymer matrix. Their size appears to be larger than in the case of PS/MB33, but the mesoscale distribution of clay is similar between the two clays. The high magnification image shows a few to several clay platelets in what appears to be an intercalated morphology. Although the TEM findings seem to contradict the XRD results, similar examples are available in the literature [25]. Apparently, the large $d$-spacing in the organo-clay allows the entry of polymer between the clay layers, without requiring an additional interlayer expansion.

Indeed, when looking at the high magnification TEMs of ABS and HIPS, the small clay structures observed for the PS nanocomposites are also apparent here (3-4 layers per stack in the case of ABS and 23 layers per stack in the case of HIPS). Overall, the morphology of PS, ABS and HIPS/MB32 nanocomposites can be assigned as a welldispersed, mostly intercalated structure, which contains a small fraction of exfoliated clay layers.

\subsection{Thermogravimetric analysis}

The motivation for the synthesis of these new surfactants was to prepare organo-clays with higher thermal stability than the commercially available alkylammonium clays, and to ascertain if the greater possibility of delocalization of the positive charge leads to enhanced thermal stability.

As can be observed from Fig. 9, both MB32 and MB33 are more thermally stable than Cloisite 20A, a typical commercially available ammonium surfactant, by almost $70^{\circ} \mathrm{C}$, in terms of temperature at $2 \%$ mass loss (Cloisite 20A was thoroughly washed to remove excess surfactant and sodium halide before use). In fact, at $300{ }^{\circ} \mathrm{C}$ (the temperature near which many high-temperature polymers are processed) the mass loss of the two benzimidazolium clays is still negligible, while the Cloisite $20 \mathrm{~A}$ has already lost $8 \%$ of its mass. Also, if the peak temperatures of degradation are compared, there is an enhancement of more than $100{ }^{\circ} \mathrm{C}$, similar to what has been reported for imidazolium clays [24] in syndiotactic-PS. The results for MB32 and MB33, summarized in Table 1 , are similar to imidazolium modified

Polymer Degradation and Stability, Vol. 92, No. 10 (October 2007): pg. 1753-1762. DOI. This article is @ Elsevier and permission has been granted for this version to appear in e-Publications@Marquette. Elsevier does not grant permission for this article to be further copied/distributed or hosted elsewhere without the express permission from Elsevier. 
clays in terms of the onset degradation temperature, but the former have a higher organic content ( 28 and 32 as compared to $25 \%$, respectively) and this may give better compatibility with the polymer matrix. It is also interesting that the presence of the methyl at the methine position was postulated as extremely important for the imidazolium clays [16], but has little effect on the thermal stability in the benzimidazolium systems studied herein.

In the TGA curves presented in Fig. 10, Fig. 11, Fig. 12, Fig. 13, Fig. 14 and Fig. 15, one can see the thermal stability enhancements brought about to all three polymers studied by the addition of clay, and the results are summarized in Table 2. It is apparent that both types of organo-clays have very similar effects on all three polymers, with no marked differences observed in the TGA behavior. For the PS system, the better thermal stability of MB32 led to a slightly larger improvement of the $T_{0.5}$, by about $7^{\circ} \mathrm{C}$ as compared to MB33.

It should be noted that enhanced thermal stability for styrene nanocomposites has been observed in virtually all cases where they have been studied [26]. The situation for polyamide- 6 nanocomposites is more complex; in some cases enhanced thermal stability has been seen by TGA [27], while in other cases there is no change in thermal stability [28]. No explanation has yet been offered for the changes, or lack thereof, in thermal stability.

\subsection{Cone calorimetric results}

The cone calorimetry results are summarized in the Table 3 and Table 4 and the heat release rate plots are shown in Fig. 16, Fig. 17, Fig. 18, Fig. 19, Fig. 20 and Fig. 21. The results are typical for polymers/clay nanocomposites: good PHRR reduction (usually associated with nanocomposite formation), an increase in the amount of the smoke, and prolonged burning times. There is very little difference, if any, between the results from the nanocomposites prepared with the two organo-clays.

As expected, at $1 \%$ clay loading there is no change in the fire properties of polymers, regardless of the organo-clay used, but as the amount of clay is increased, the reduction in the peak heat release rate, PHRR, becomes more important.

Polymer Degradation and Stability, Vol. 92, No. 10 (October 2007): pg. 1753-1762. DOI. This article is @ Elsevier and permission has been granted for this version to appear in e-Publications@Marquette. Elsevier does not grant permission for this article to be further copied/distributed or hosted elsewhere without the express permission from Elsevier. 
Also, it is significant that even at higher clay loading the time to ignition did not decrease for any of the systems studied, while there is normally a decrease in this property with other organically-modified clays. This interesting observation is of particular importance, since it may suggest that there could be a simple answer to the early ignition problem of polymer-layered silicate nanocomposites.

As is normal for polymer-clay nanocomposites, there is no change in the total heat released, which means that the polymer does completely burn, and there is essentially no change in the amount of smoke (ASEA) that is evolved. It is usually felt that the change in the peak heat release rate occurs due to a change in the mass loss rate and there is a comparable reduction in both with both surfactants and all three polymers. The two clays give similar results and are comparable to literature data for PS, ABS and HIPS [25], [29], [30] and [31]. Also the TGA behavior is comparable to nanocomposites of crystallizable syndiotactic-PS with alkyl-imidazolium modified montmorillonites [24]. Unfortunately, since there are no reports on cone calorimetric results for imidazolium-clay styrenic nanocomposites, it is not possible to compare these systems.

It is of interest to compare these results with those for a commercial clay, such as Cloisite 20A, which contains two long tails. Work on Cloisite 20A has been previously published [32] but these systems were prepared by bulk polymerization rather than melt blending and the dispersion is frequently better by bulk polymerization than may be achieved by melt blending. This is certainly true in this case if one uses the reduction in the PHRR as an indication of the extent of dispersion. In previous work from these laboratories, it has been shown that a smaller reduction in the PHRR is indicative of poorer dispersion [25], [29] and [30]. Gilman has also shown that a microcomposite gives essentially no reduction in the PHRR while a well-dispersed nanocomposite gives a substantial reduction [33]. The reduction in PHRR for the bulk polymerized PS with Cloisite $20 \mathrm{~A}$ is $53 \%$ while with BZ33, the closest analogue of the two materials used in this investigation, the reduction is $36 \%$. A portion of this difference could be due to the better dispersion that is usually obtained by bulk polymerization. When a nanocomposite was prepared using melt blending of Cloisite $20 \mathrm{~A}$, the reduction is $38 \%$, which is very comparable to that seen in this system, $36 \%$. One must conclude that

Polymer Degradation and Stability, Vol. 92, No. 10 (October 2007): pg. 1753-1762. DOI. This article is @ Elsevier and permission has been granted for this version to appear in e-Publications@Marquette. Elsevier does not grant permission for this article to be further copied/distributed or hosted elsewhere without the express permission from Elsevier. 
this new surfactant is as good as Cloisite 20A for nanocomposite formation.

\section{Conclusions}

Two benzimidazolium surfactants have been synthesized and successfully exchanged onto montmorillonite. Both of these organically-modified clays have enhanced thermal stability compared to the conventional ammonium-based organo-clays and are comparable with the imidazolium-treated clays, showing promise for utilization with higher melting polymers. Unlike imidazolium, substitution at the 2-position of benzimidazolium is not required in order to achieve high thermal stability for the modified clays, but it seems to allow a better entry of the polymer into the clay intergallery space and, therefore, better dispersion. When melt blended with PS, ABS and HIPS, both clays led to the formation of mostly intercalated nanocomposites and showed good mesoscale dispersion. The fire properties of the nanocomposites were improved, especially in terms of the reduction in the peak heat release rate, and are comparable to those of melt blended Cloisite 20A, which may be considered a model for these new systems.

\section{Acknowledgment}

We gratefully acknowledge the skilled work of Vin Berry in obtaining the TEM images of the MB33 nanocomposites. The work at Penn State was supported through an ES\&F grant from PSU/ARL.

\section{References}

1. Theng BKG. Clay Miner 1970;18:357-62 (and references therein).

2. Kojima Y, Usuki A, Kawasumi M, Okada A, Fukushima Y, Kurauchi T. J Mater Res 1993;8:1185-9.

3. Okada A, Usuki A. Mater Sci Eng C 1995;3:115.

4. Giannelis EP, Krishnamoorti RK, Manias E. Adv Polym Sci 1998;138:10748.

5. Alexander M, Dubois P. Mater Sci Eng R 2000;28: 1-63.

6. Ray SS, Okamoto M. Prog Polym Sci 2003;28:1539-641.

Polymer Degradation and Stability, Vol. 92, No. 10 (October 2007): pg. 1753-1762. DOI. This article is @ Elsevier and permission has been granted for this version to appear in e-Publications@Marquette. Elsevier does not grant permission for this article to be further copied/distributed or hosted elsewhere without the express permission from Elsevier. 
NOT THE PUBLISHED VERSION; this is the author's final, peer-reviewed manuscript. The published version may be accessed by following the link in the citation at the bottom of the page.

7. Utracki LA, Sepehr M, Boccaleri E. Polym Adv TechnoI 2007;18:1-37.

8. Davis CH, Mathis LJ, Gilman JW, Schiraldi DA, Shields JR, Trulove P, et al. J Polym Sci Part B: Polym Phys 2002;40:2661-6.

9. VanderHart DL, Asano A, Gilman JW. Macromolecules 2001;34:3919.

10. VanderHart DL, Asano A, Gilman JW, Chem Mater 2001;13(10):3796-809.

11. Shah RK, Paul DR. Polymer 2006;47:4084.

12. Fornes TD, Yoon, Paul DR. Polymer 2003;44:7545-56.

13. Yoon PJ, Hunter DL, Paul DR. Polymer 2003;44:5323-39.

14. Yoon PJ, Hunter DL, Paul DR. Polymer 2003;44:5341-54.

15. Xie W, Gao Z, Pan W, Hunter D, Singh A, Vaia R. Chem Mater 2001;13:2979-90.

16. Gilman JW, Awad WH, Davis RD, Shields J, Harris Jr RH, Davis C, et al. Chem Mater 2002;14:3776-85.

17. Zhu J, Uhl FM, Morgan AB, Wilkie CA. Chem Mater 2001;13(12):4649-54.

18. Zhu J, Morgan AB, Lamelas FJ, Wilkie CA. Chem Mater 2001;13:3774-80.

19. Zhang J, Jiang DD, Wilkie CA. Thermochim Acta 2005;430:107-13.

20. Chigwada G, Wang D, Wilkie CA. Polym Degrad Stab 2006;91:848-55.

21. Costache MC, Heidecker MJ, Manias E, Wilkie CA. Polym Adv Technol 2006;17:764-71.

22. Wilkes JS, Lavesky JA, Wilson RA, Hussey CL. Inorg Chem 1982;21:12634.

23. Ngo HL, LeCompte $\mathrm{K}$, Hargens L, McEwen AB. Thermochim Acta $2000 ; 97: 357$.

24. Wang ZM, Chung TC, Gilman JW, Manias E. J Polym Sci B Polym Phys 2003;41:3285-98.

25. Chigwada G, Wang D, Jiang DD, Wilkie CA. Polym Degrad Stab 2006;91:755-62.

26. Jang BN, Wilkie CA. Polymer 2005;46:2933-42.

27. Paramoda KP, Liu T, Liu Z, He C, Sue HJ. Polym Degrad Stab 2003;81:4756.

Polymer Degradation and Stability, Vol. 92, No. 10 (October 2007): pg. 1753-1762. DOI. This article is @ Elsevier and permission has been granted for this version to appear in e-Publications@Marquette. Elsevier does not grant permission for this article to be further copied/distributed or hosted elsewhere without the express permission from Elsevier. 
28. Kashiwagi $T$, Harris RH, Zhang $X$, Briber RM, Cipriano BH, Raghavan SR, et al. Polymer 2004;45:881-91; Dabrowski F, Bourbigot S, Delobel R, Le Bras M. Eur Polym J 2000;36:273-84; Jang BN, Wilkie CA. Polymer 2005;46:3264-74.

29. Su S, Jiang DD, Wilkie CA. Polym Degrad Stab 2004;84:279-88.

30. Zheng X, Wilkie CA. Polym Degrad Stab 2003;82:441-50.

31. Gilman JW, Jackson CL, Morgan AB, Manias E, Giannelis EP, Wuthenow $M$, et al. Chem Mater 2000;12:1866-73.

32. Zhu J, Wilkie CA. Polym Int 2000;49:1158-63.

33. Gilman JW, Kashiwagi T, Gainellis EP, Manias E, Lomakin S, Lichentan JD, et al. In: LeBras M, Bourbigot S, Delobel R, editors. Fire retardancy: the use of intumesence. Cambridge: Royal Society of Chemistry; 1998. p. 203-21.

\section{About the Authors}

Charles A. Wilkie : Deparment of Chemistry, Marquette University, P.O. Box 1881, Milwaukee, WI 53201, USA

Email: charles.wilkie@marquette.edu

\section{Appendix}

Table 1: Thermal stability data for benzimidazolium and alkylammonium-treated montmorillonites

\begin{tabular}{lllc}
\hline Sample & $\begin{array}{l}\text { Onset degradation } \\
\text { temperature } T_{0.02}\left({ }^{\circ} \mathrm{C}\right)\end{array}$ & $\begin{array}{l}\text { Peak decomposition } \\
\text { temperature }\left({ }^{\circ} \mathrm{C}\right)\end{array}$ & $\begin{array}{l}\text { Organic } \\
\text { fraction }(\%)\end{array}$ \\
\hline 20A & 275 & 320 & 35 \\
MB32 & 340 & 424 & $32^{\mathrm{a}}$ \\
MB33 & 315 & 430 & $28^{\mathrm{a}}$ \\
\hline
\end{tabular}

a The organic fraction at $600^{\circ} \mathrm{C}$ is in good agreement with the theoretical calculations, based on the cation exchange capacity (CEC) of the clay.

Polymer Degradation and Stability, Vol. 92, No. 10 (October 2007): pg. 1753-1762. DOI. This article is @ Elsevier and permission has been granted for this version to appear in e-Publications@Marquette. Elsevier does not grant permission for this article to be further copied/distributed or hosted elsewhere without the express permission from Elsevier. 
NOT THE PUBLISHED VERSION; this is the author's final, peer-reviewed manuscript. The published version may be accessed by following the link in the citation at the bottom of the page.

Table 2: Summary of TGA results for MB32 and MB33-based nanocomposites

\begin{tabular}{llllll}
\hline Sample (clay loading, \%) & \multicolumn{2}{l}{$T_{0.1}\left({ }^{\circ} \mathrm{C}\right)$} & & \multicolumn{2}{l}{$T_{0.5}\left({ }^{\circ} \mathrm{C}\right)$} \\
\cline { 2 - 3 } & MB32 & MB33 & & MB32 & MB33 \\
\hline Virgin PS & 386 & 386 & & 423 & 423 \\
PS/clay (1\%) & 403 & 403 & & 433 & 427 \\
PS/clay (3\%) & 403 & 406 & & 437 & 434 \\
Virgin ABS & 411 & 411 & & 434 & 434 \\
ABS/clay (1\%) & 415 & 414 & & 443 & 442 \\
ABS/clay (3\%) & 415 & 414 & & 444 & 444 \\
Virgin HIPS & 421 & 21 & & 445 & 445 \\
HIPS/clay (1\%) & 422 & 422 & & 453 & 447 \\
HIPS/clay (3\%) & 421 & 424 & & 457 & 454 \\
\hline
\end{tabular}

$T_{0.1}=$ temperature at $10 \%$ mass loss; $T_{0.5}=$ temperature at $50 \%$ mass loss.

Table 3: Cone calorimetry results for styrenics/MB32 nanocomposites (heat flux of $35 \mathrm{~kW} / \mathrm{m} 2$ )

\begin{tabular}{lclclll}
\hline Formulation & PHRR $\left(\mathrm{kW} / \mathrm{m}^{2}\right)$ & Reduct $(\%)$ & THR $\left(\mathrm{MJ} / \mathrm{m}^{2}\right)$ & ASEA $\left(\mathrm{m}^{2} / \mathrm{kg}\right)$ & AMLR $\left(\mathrm{g} / \mathrm{sm}^{2}\right)$ & $t_{\text {ig }}$ \\
\hline PS virgin & $1334 \pm 68$ & NA & $98 \pm 2$ & $1158 \pm 23$ & $31.7 \pm 1.5$ & $52 \pm 1.2$ \\
PS/MB32 (1\%) & $1219 \pm 93$ & 9 & $97 \pm 5$ & $1162 \pm 18$ & $31.8 \pm 1.5$ \\
PS/MB32 (3\%) & $844 \pm 40$ & 37 & $96 \pm 3$ & $1284 \pm 19$ & $21.8 \pm 0.7$ & $54 \pm 2.2$ \\
ABS & $1146 \pm 71$ & NA & $102 \pm 3$ & $1172 \pm 9$ & $28.9 \pm 1.3$ & $70 \pm 7.6$ \\
ABS/MB32 (1\%) & $1217 \pm 47$ & 6 & $96 \pm 1$ & $1202 \pm 14$ & $30.5 \pm 1.2$ & $70 \pm 1.6$ \\
ABS/MB32 (3\%) & $983 \pm 28$ & 14 & $98 \pm 5$ & $1251 \pm 17$ & $24.4 \pm 0.6$ & $70 \pm 1.1$ \\
HIPS & $1320 \pm 77$ & NA & $112 \pm 3$ & $1254 \pm 14$ & $30.5 \pm 0.7$ & $63 \pm 2.3$ \\
HIPS/MB32 (1\%) & $1264 \pm 2$ & 4 & $100 \pm 2$ & $1297 \pm 7$ & $14.7 \pm 2.8$ & $58 \pm 0.2$ \\
HIPS/MB32 (3\%) & $954 \pm 36$ & 28 & $100 \pm 1$ & $1362 \pm 22$ & $22.3 \pm 0.2$ & $66 \pm 3.3$
\end{tabular}

PHRR, peak heat release rate; THR, total heat release; ASEA, average specific extinction area, a measure of smoke; AMLR, average mass loss rate; $t_{\mathrm{ig}}$, time to ignition.

Polymer Degradation and Stability, Vol. 92, No. 10 (October 2007): pg. 1753-1762. DOI. This article is @ Elsevier and permission has been granted for this version to appear in e-Publications@Marquette. Elsevier does not grant permission for this article to be further copied/distributed or hosted elsewhere without the express permission from Elsevier. 
NOT THE PUBLISHED VERSION; this is the author's final, peer-reviewed manuscript. The published version may be accessed by following the link in the citation at the bottom of the page.

Table 4: Cone calorimetry results for styrenics/MB33 nanocomposites (heat flux of $35 \mathrm{~kW} / \mathrm{m} 2$ )

\begin{tabular}{|c|c|c|c|c|c|c|}
\hline Formulation & $\operatorname{PHRR}\left(\mathrm{kW} / \mathrm{m}^{2}\right)$ & Reduct (\%) & THR $\left(\mathrm{MJ} / \mathrm{m}^{2}\right)$ & $\operatorname{ASEA}\left(\mathrm{m}^{2} / \mathrm{kg}\right)$ & $\operatorname{AMLR}\left(\mathrm{g} / \mathrm{sm}^{2}\right)$ & $t_{\text {ig }}$ \\
\hline PS virgin & $1449 \pm 46$ & NA & $93 \pm 2$ & $1258 \pm 18$ & $34.4 \pm 0.8$ & $55 \pm 2.0$ \\
\hline PS/MB33 (1\%) & $1409 \pm 36$ & 3 & $97 \pm 3$ & $1207 \pm 33$ & $34.0 \pm 0.9$ & $54 \pm 4.9$ \\
\hline PS/MB33 (3\%) & $934 \pm 64$ & 36 & $96 \pm 1$ & $1362 \pm 8$ & $24.2 \pm 1.3$ & $53 \pm 5.5$ \\
\hline $\mathrm{ABS}$ & $1164 \pm 23$ & NA & $97 \pm 3$ & $1269 \pm 13$ & $27.7 \pm 1.4$ & $54 \pm 2.0$ \\
\hline ABS/MB33 (1\%) & $1150 \pm 30$ & 1 & $98 \pm 3$ & $1301 \pm 13$ & $27.9 \pm 0.6$ & $50 \pm 2.4$ \\
\hline ABS/MB33 (3\%) & $989 \pm 27$ & 15 & $98 \pm 2$ & $1358 \pm 12$ & $24.7 \pm 0.7$ & $54 \pm 1.6$ \\
\hline HIPS & $1213 \pm 25$ & NA & $107 \pm 4$ & $1435 \pm 32$ & $28.0 \pm 0.9$ & $62 \pm 1.9$ \\
\hline HIPS/MB33 (1\%) & $1215 \pm 15$ & 0 & $107 \pm 3$ & $1444 \pm 55$ & $28.6 \pm 0.7$ & $62 \pm 2.8$ \\
\hline HIPS/MB33 (3\%) & $882 \pm 1$ & 27 & $103 \pm 1$ & $1499 \pm 3$ & $21.8 \pm 0.8$ & $58 \pm 0.2$ \\
\hline
\end{tabular}

PHRR, peak heat release rate; THR, total heat release; ASEA, average specific extinction area, a measure of smoke; AMLR, average mass loss rate; $t_{\mathrm{ig}}$, time to ignition.

Scheme 1.: Benzimidazole derivatives and benzimidazolium halides.

(1)<smiles>CC(C)Cn1cnc2ccccc21</smiles>

(3)<smiles>Cc1nc2ccccc2n1CC(C)C</smiles>

(2)<smiles></smiles>

BZ 32

(4)<smiles></smiles>

BZ 33 
NOT THE PUBLISHED VERSION; this is the author's final, peer-reviewed manuscript. The published version may be accessed by following the link in the citation at the bottom of the page.

Fig. 1.: XRD patterns of MB33 and PS, ABS and HIPS nanocomposites.

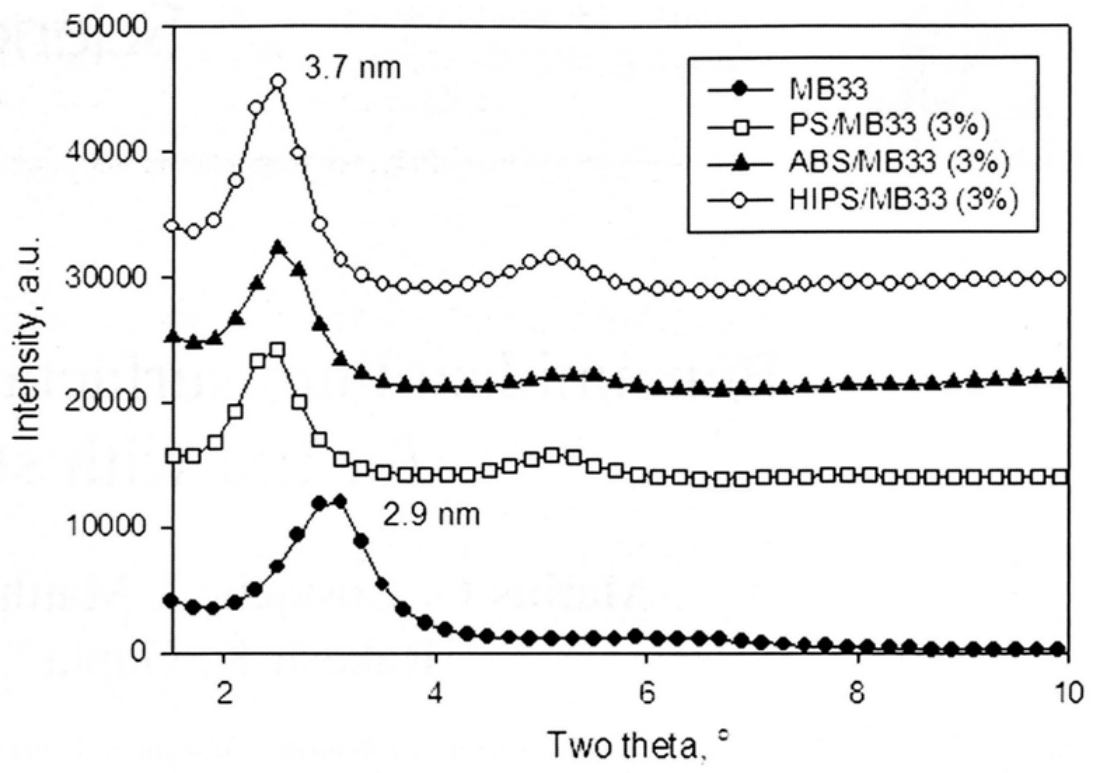

Fig. 2.: TEM micrographs of PS/MB33 (3\%) nanocomposite at low and high magnification (left and right, respectively).
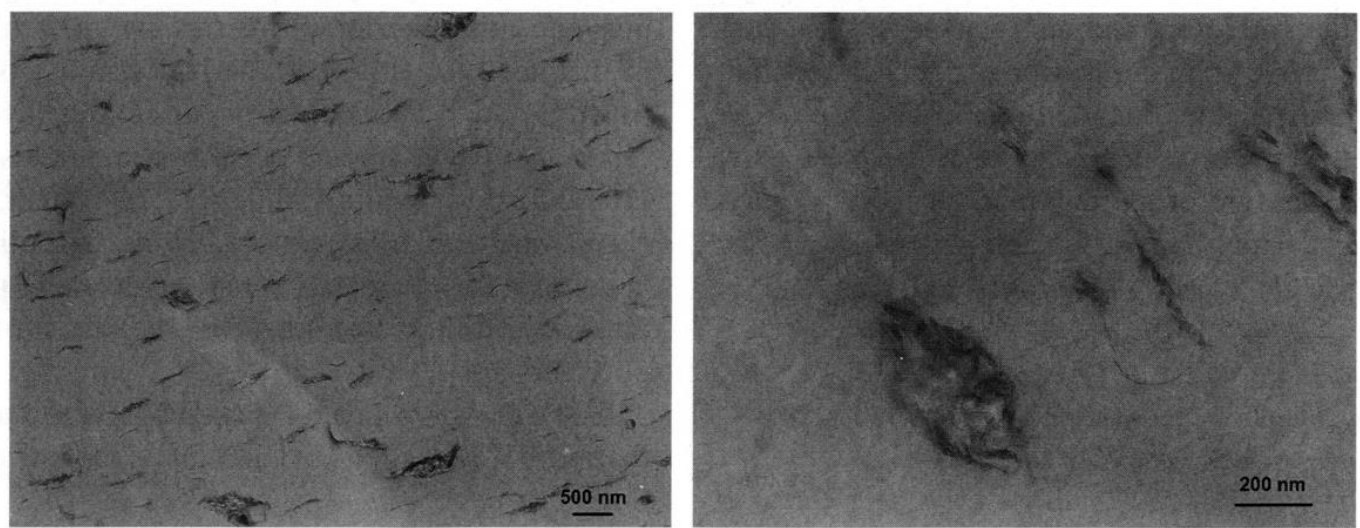

Polymer Degradation and Stability, Vol. 92, No. 10 (October 2007): pg. 1753-1762. DOI. This article is @ Elsevier and permission has been granted for this version to appear in e-Publications@Marquette. Elsevier does not grant permission for this article to be further copied/distributed or hosted elsewhere without the express permission from Elsevier. 
NOT THE PUBLISHED VERSION; this is the author's final, peer-reviewed manuscript. The published version may be accessed by following the link in the citation at the bottom of the page.

Fig. 3.: TEM micrographs of ABS/MB33 (3\%) at low and high magnification (left and right, respectively); $a=$ clay particles, $b=$ rubber particles, $c=$ possible crazing in the PS matrix.
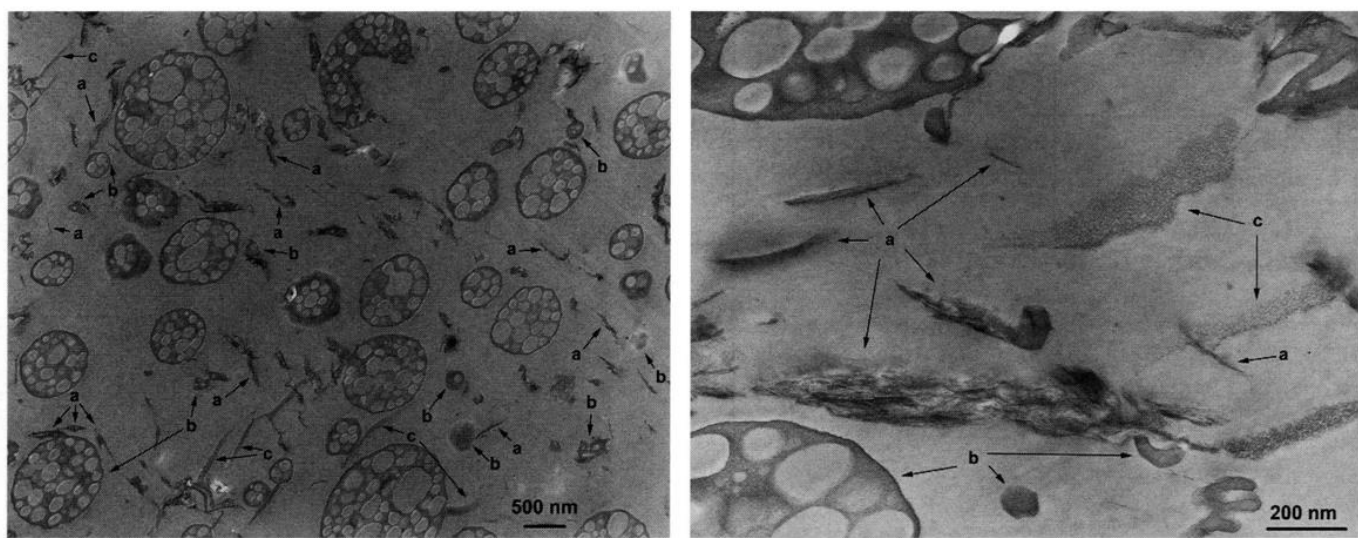

Fig. 4.: TEM micrographs of HIPS/MB33 (3\%) at low and high magnification (left and right, respectively); $a=$ clay particles, $b=$ rubber particles, $c=$ possible crazing in the PS matrix.
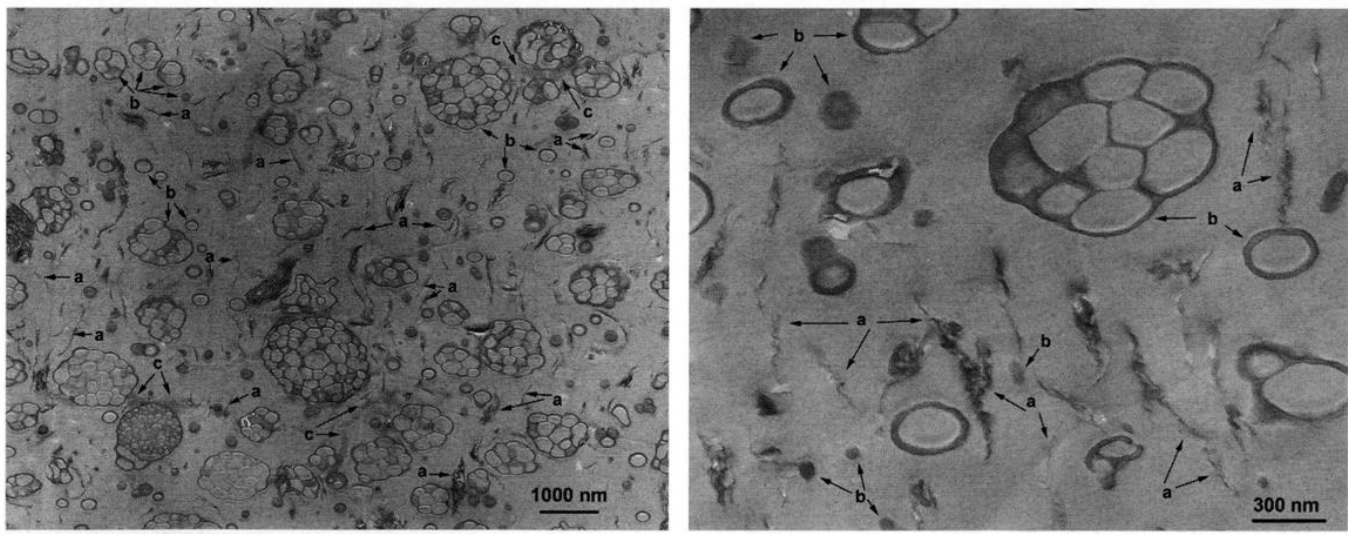

Polymer Degradation and Stability, Vol. 92, No. 10 (October 2007): pg. 1753-1762. DOI. This article is @ Elsevier and permission has been granted for this version to appear in e-Publications@Marquette. Elsevier does not grant permission for this article to be further copied/distributed or hosted elsewhere without the express permission from Elsevier. 
NOT THE PUBLISHED VERSION; this is the author's final, peer-reviewed manuscript. The published version may be accessed by following the link in the citation at the bottom of the page.

Fig. 5.: XRD patterns of MB32 and PS, ABS and HIPS nanocomposites.

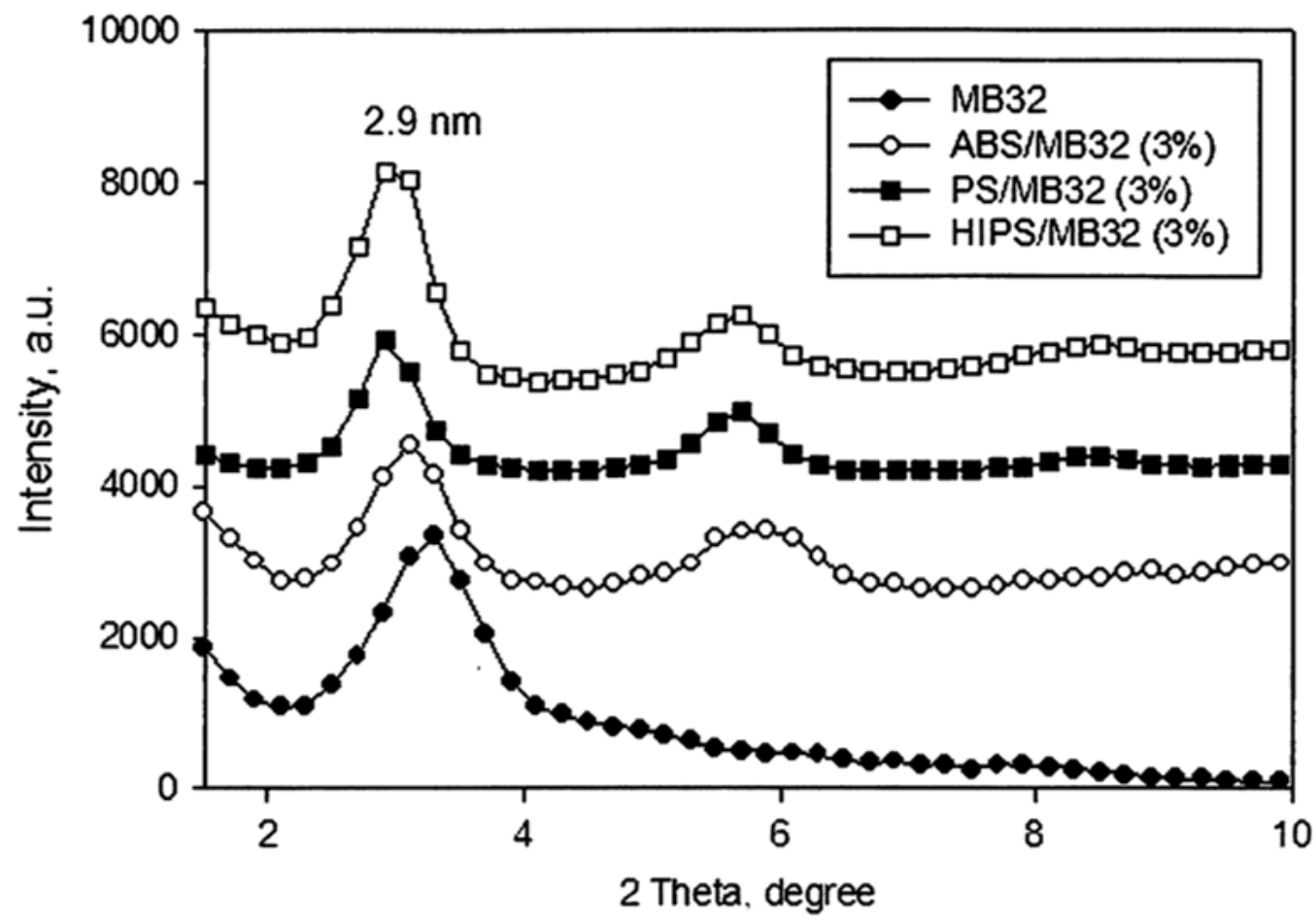

Fig. 6.: TEM micrographs of PS/MB32 (3\%) nanocomposite at low and high magnification (left and right, respectively).
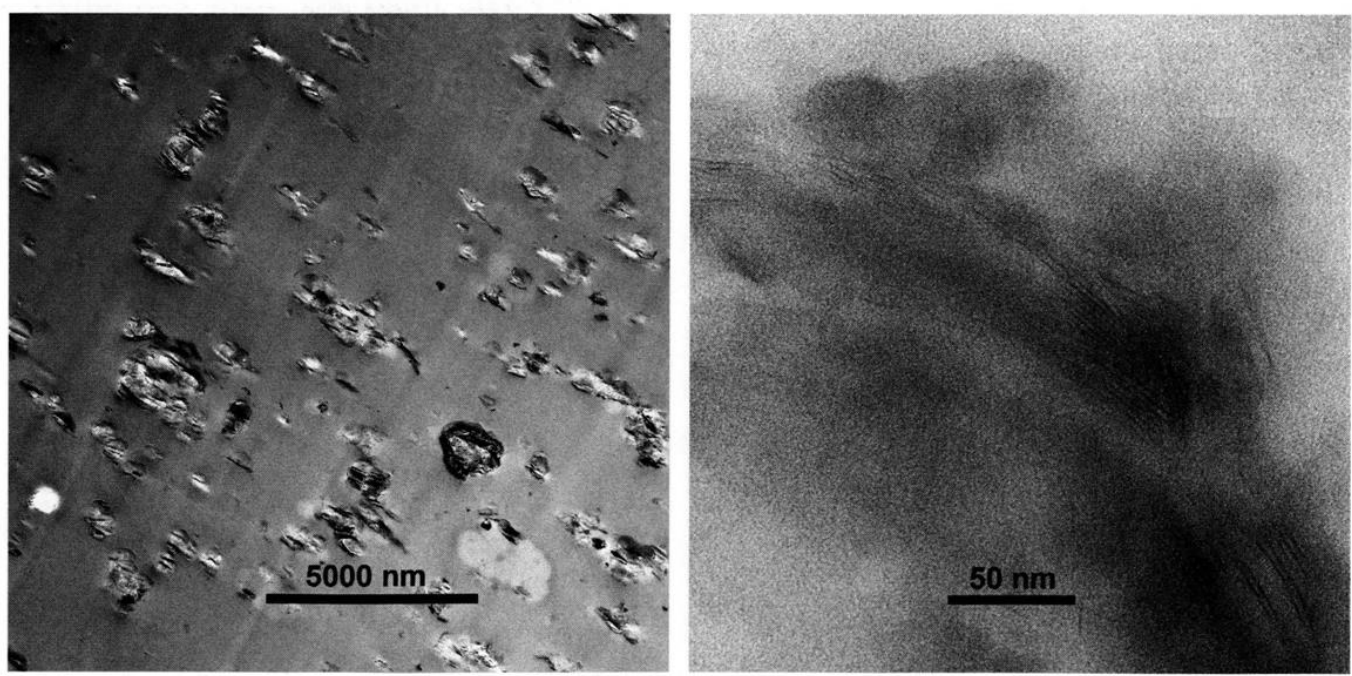

Polymer Degradation and Stability, Vol. 92, No. 10 (October 2007): pg. 1753-1762. DOI. This article is (C) Elsevier and permission has been granted for this version to appear in e-Publications@Marquette. Elsevier does not grant permission for this article to be further copied/distributed or hosted elsewhere without the express permission from Elsevier. 
NOT THE PUBLISHED VERSION; this is the author's final, peer-reviewed manuscript. The published version may be accessed by following the link in the citation at the bottom of the page.

Fig. 7.: TEM micrographs of ABS/MB32 (3\%) nanocomposite at high magnification.

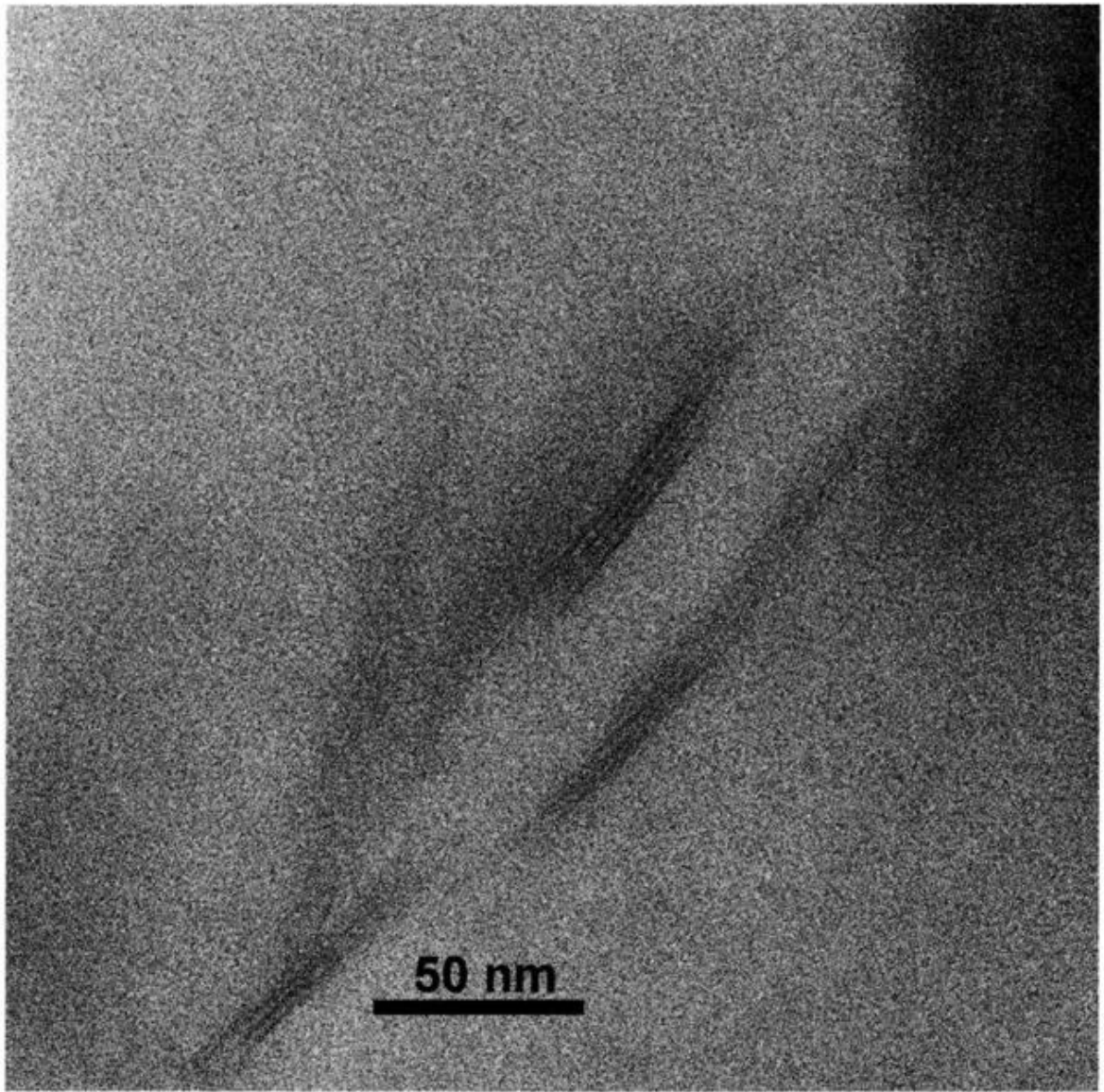

Polymer Degradation and Stability, Vol. 92, No. 10 (October 2007): pg. 1753-1762. DOI. This article is (C) Elsevier and permission has been granted for this version to appear in e-Publications@Marquette. Elsevier does not grant permission for this article to be further copied/distributed or hosted elsewhere without the express permission from Elsevier. 
NOT THE PUBLISHED VERSION; this is the author's final, peer-reviewed manuscript. The published version may be accessed by following the link in the citation at the bottom of the page.

Fig. 8.: TEM micrographs of HIPS/MB32 (3\%) nanocomposite at high magnification.

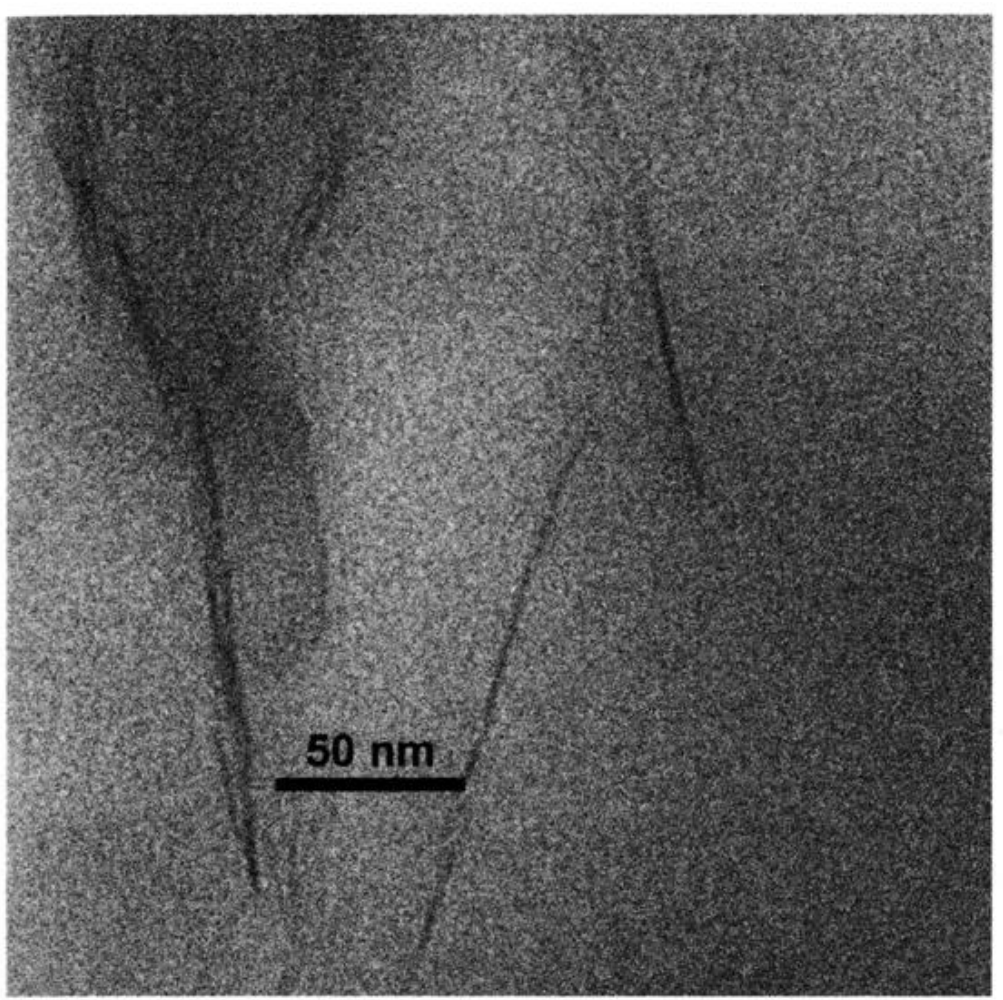

Fig. 9.: TGA curves of Cloisite 20A, MB32 and MB33.

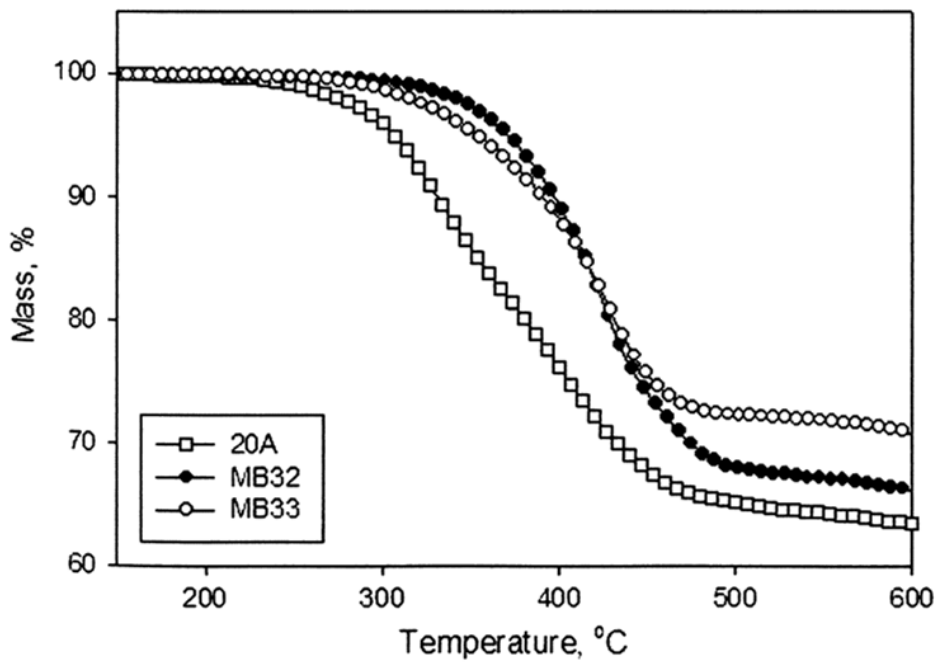

Polymer Degradation and Stability, Vol. 92, No. 10 (October 2007): pg. 1753-1762. DOI. This article is (C) Elsevier and permission has been granted for this version to appear in e-Publications@Marquette. Elsevier does not grant permission for this article to be further copied/distributed or hosted elsewhere without the express permission from Elsevier. 
NOT THE PUBLISHED VERSION; this is the author's final, peer-reviewed manuscript. The published version may be accessed by following the link in the citation at the bottom of the page.

Fig. 10.: TGA curves of PS and its nanocomposites at 1 and $3 \%$ modified clay loading.

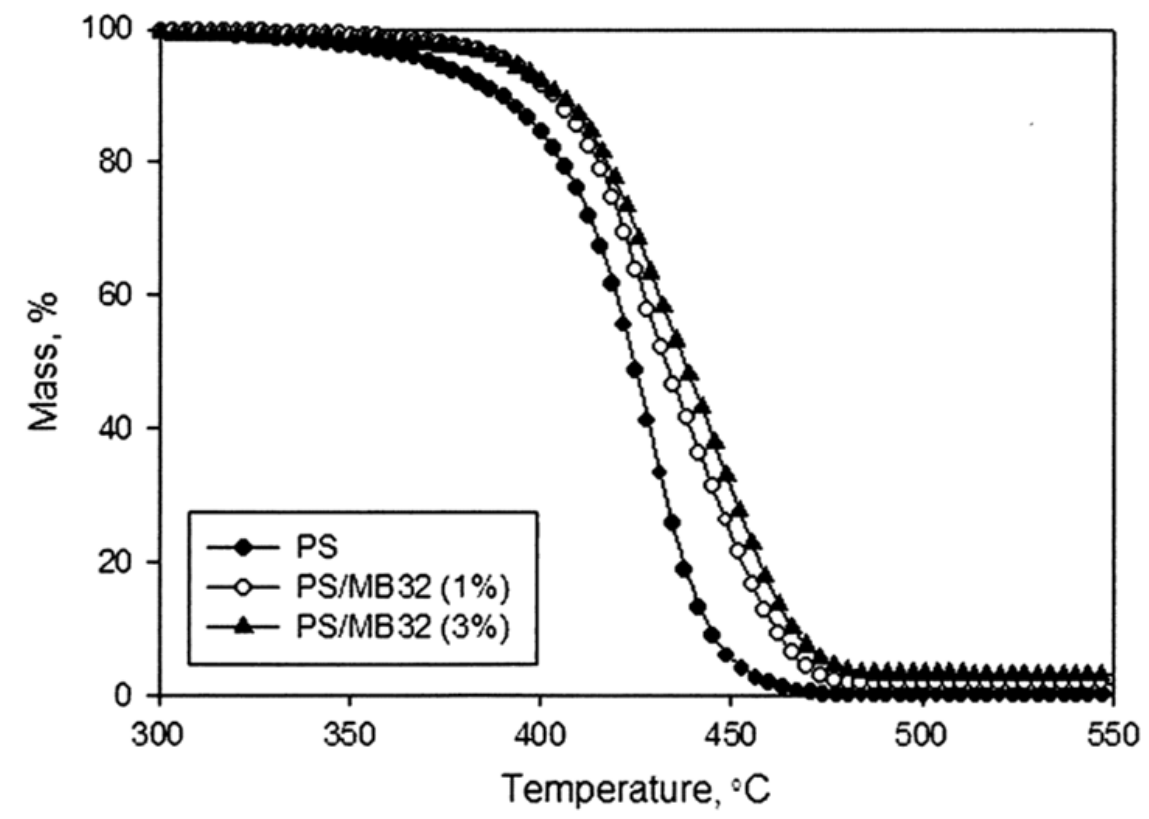

Fig. 11.: TGA curves of $A B S$ and its nanocomposites at 1 and $3 \%$ modified clay loading.

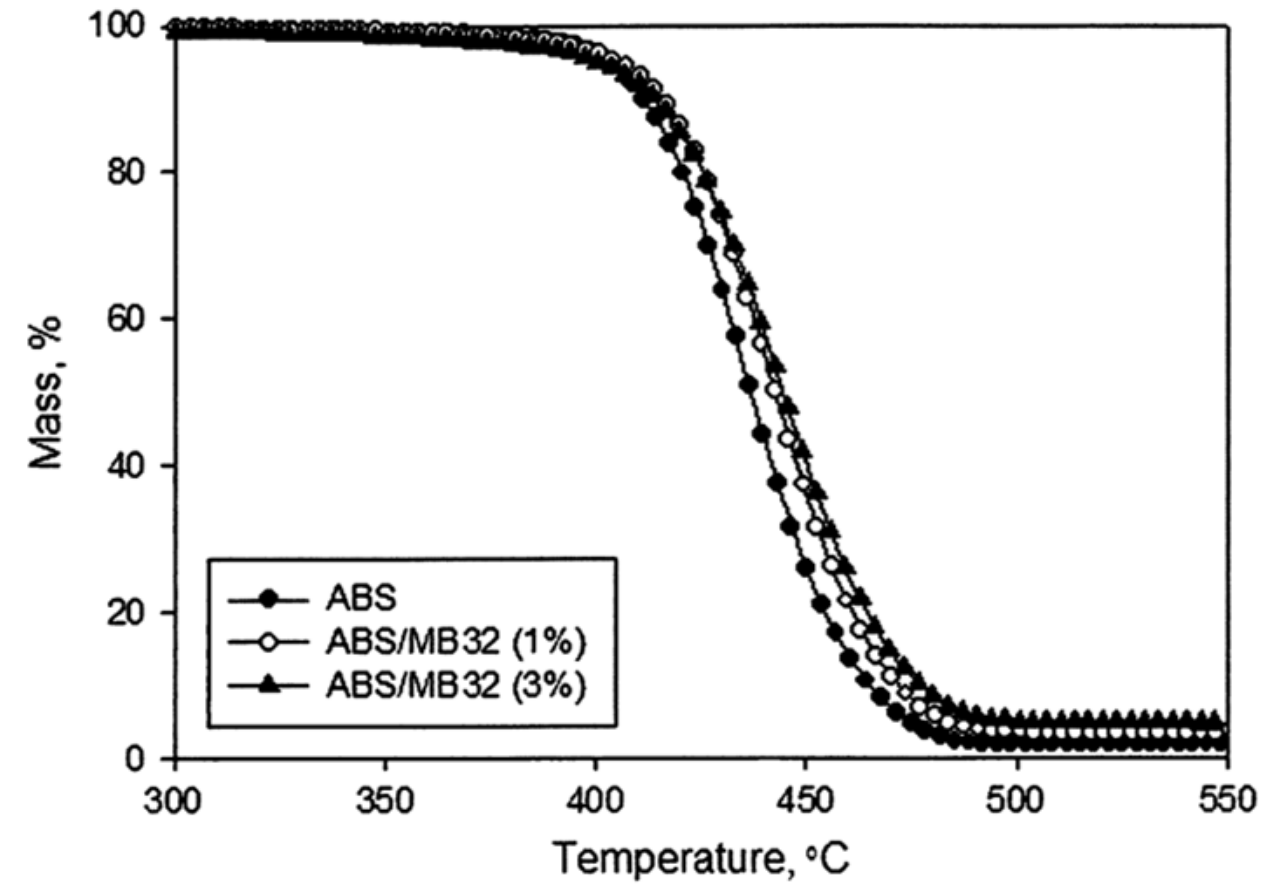

Polymer Degradation and Stability, Vol. 92, No. 10 (October 2007): pg. 1753-1762. DOI. This article is (C Elsevier and permission has been granted for this version to appear in e-Publications@Marquette. Elsevier does not grant permission for this article to be further copied/distributed or hosted elsewhere without the express permission from Elsevier. 
NOT THE PUBLISHED VERSION; this is the author's final, peer-reviewed manuscript. The published version may be accessed by following the link in the citation at the bottom of the page.

Fig. 12.: TGA curves of HIPS and its nanocomposites at 1 and $3 \%$ modified clay loading.

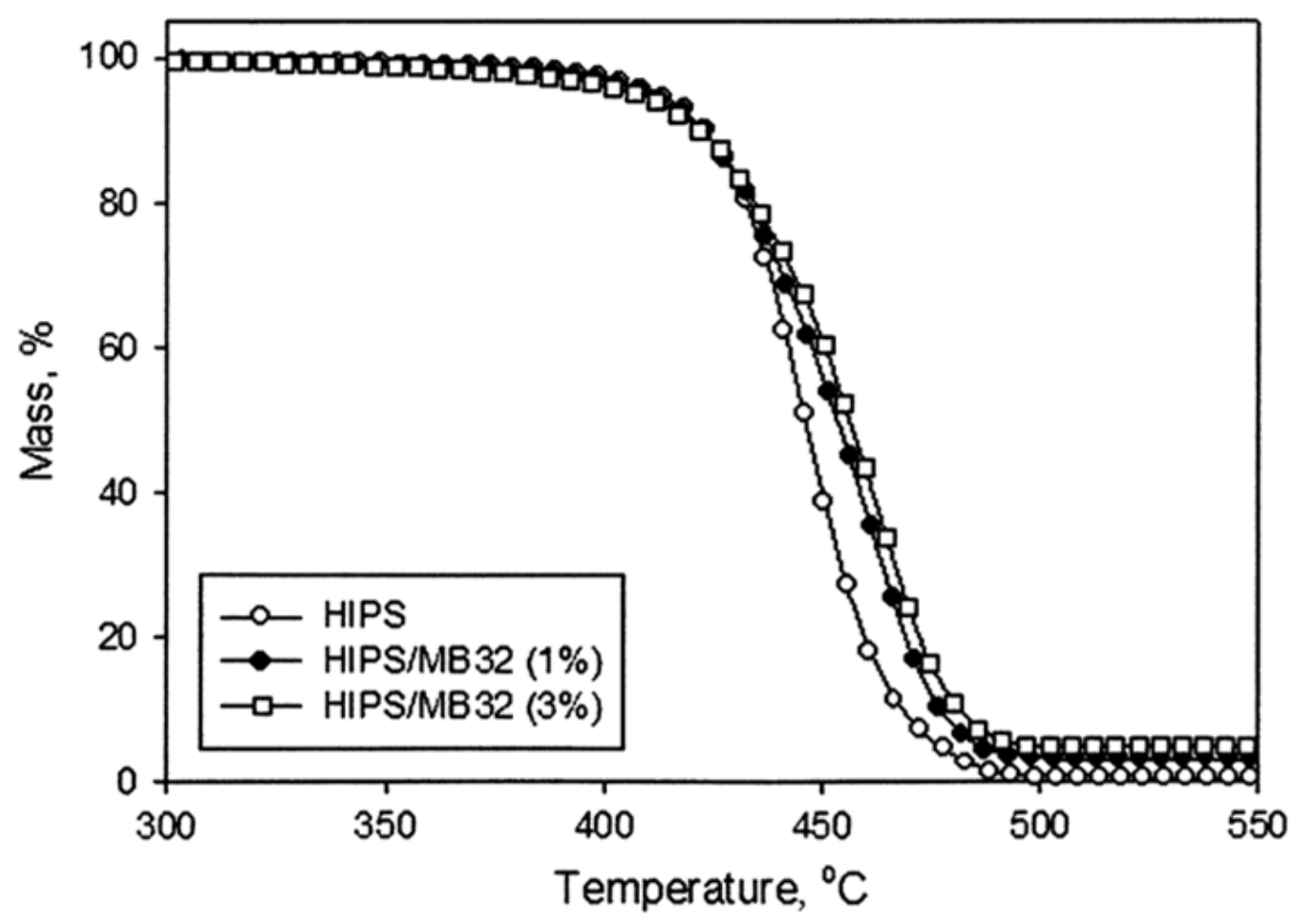

Fig. 13.: TGA curves of PS and its nanocomposites at 1 and $3 \%$ modified clay loading.

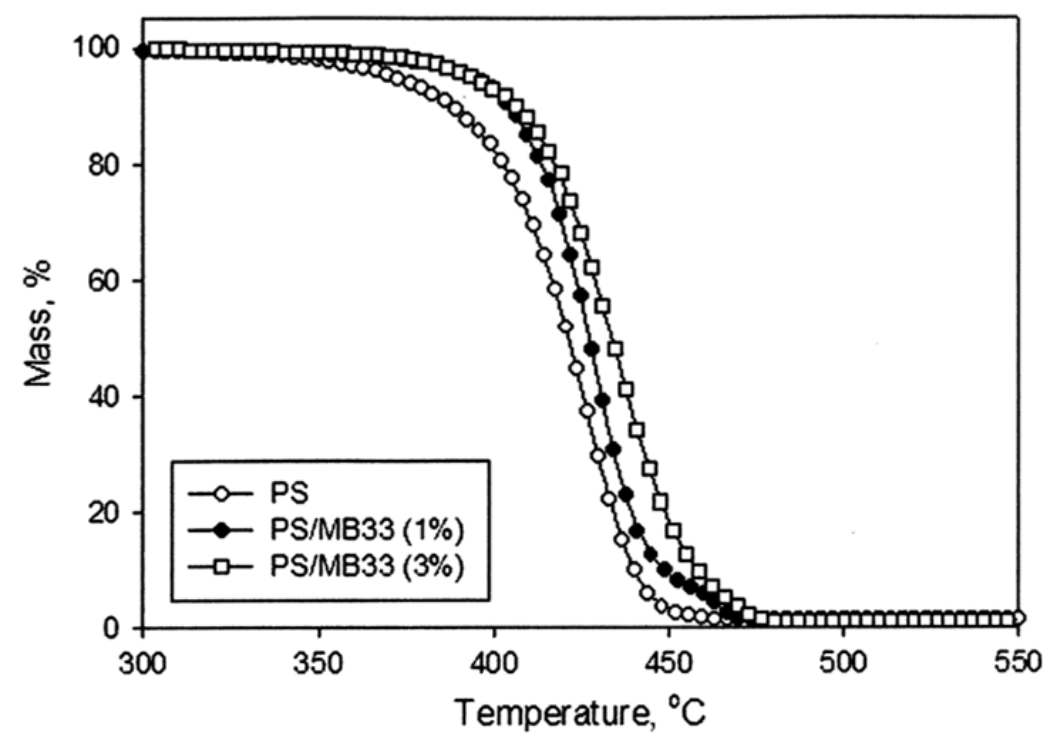

Polymer Degradation and Stability, Vol. 92, No. 10 (October 2007): pg. 1753-1762. DOI. This article is @ Elsevier and permission has been granted for this version to appear in e-Publications@Marquette. Elsevier does not grant permission for this article to be further copied/distributed or hosted elsewhere without the express permission from Elsevier. 
NOT THE PUBLISHED VERSION; this is the author's final, peer-reviewed manuscript. The published version may be accessed by following the link in the citation at the bottom of the page.

Fig. 14.: TGA curves of $A B S$ and its nanocomposites at 1 and $3 \%$ modified clay loading.

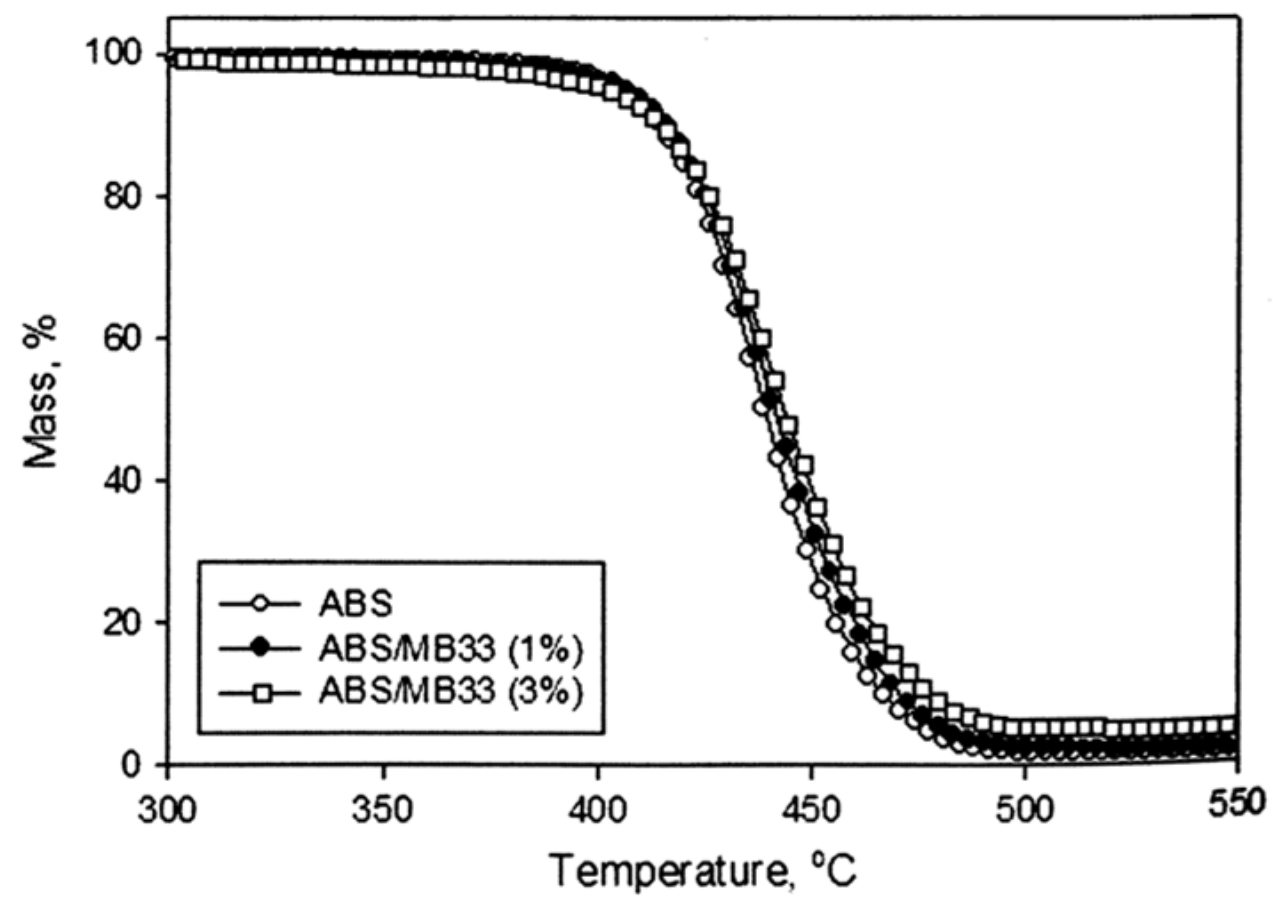

Fig. 15.: TGA curves of HIPS and its nanocomposites at 1 and $3 \%$ modified clay loading.

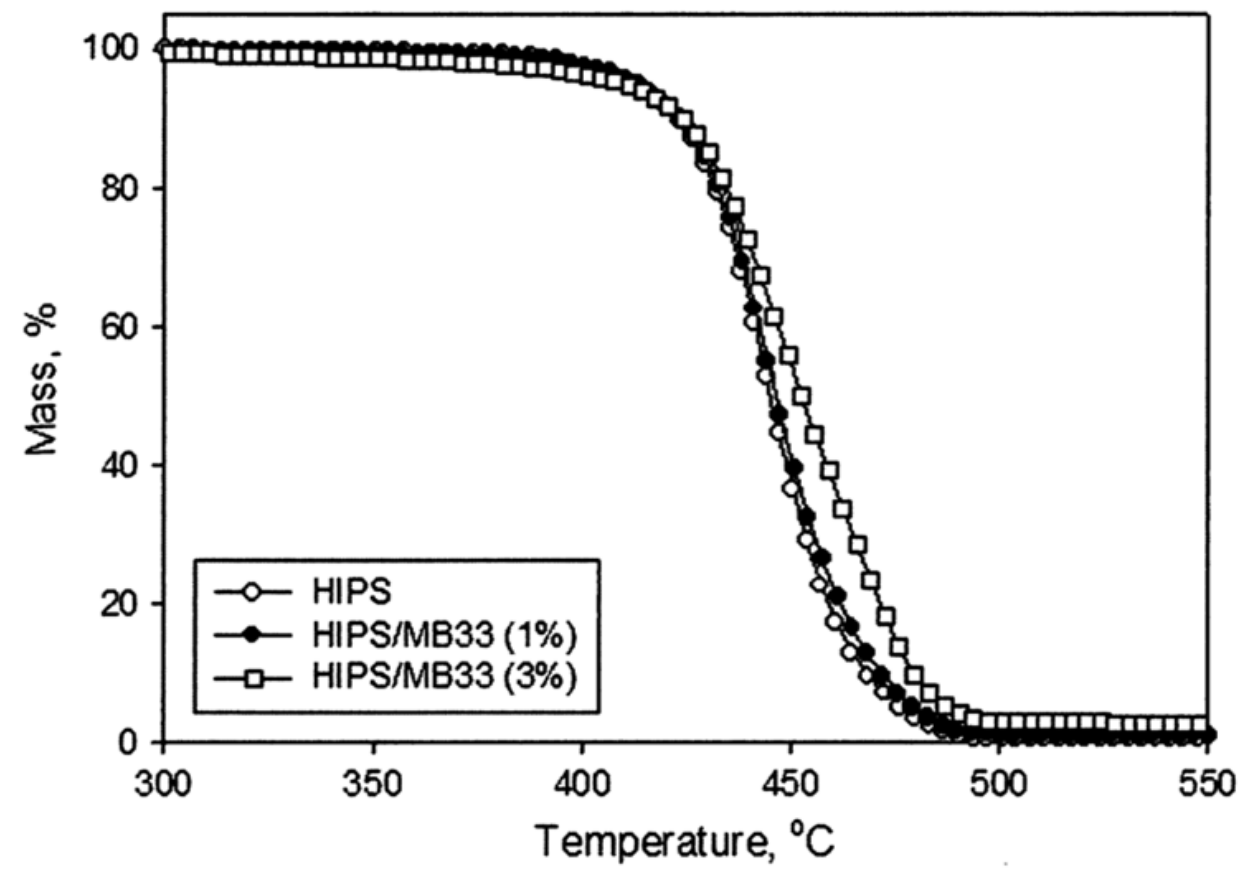

Polymer Degradation and Stability, Vol. 92, No. 10 (October 2007): pg. 1753-1762. DOI. This article is @ Elsevier and permission has been granted for this version to appear in e-Publications@Marquette. Elsevier does not grant permission for this article to be further copied/distributed or hosted elsewhere without the express permission from Elsevier. 
NOT THE PUBLISHED VERSION; this is the author's final, peer-reviewed manuscript. The published version may be accessed by following the link in the citation at the bottom of the page.

Fig. 16.: HRR plots for PS and its nanocomposites.

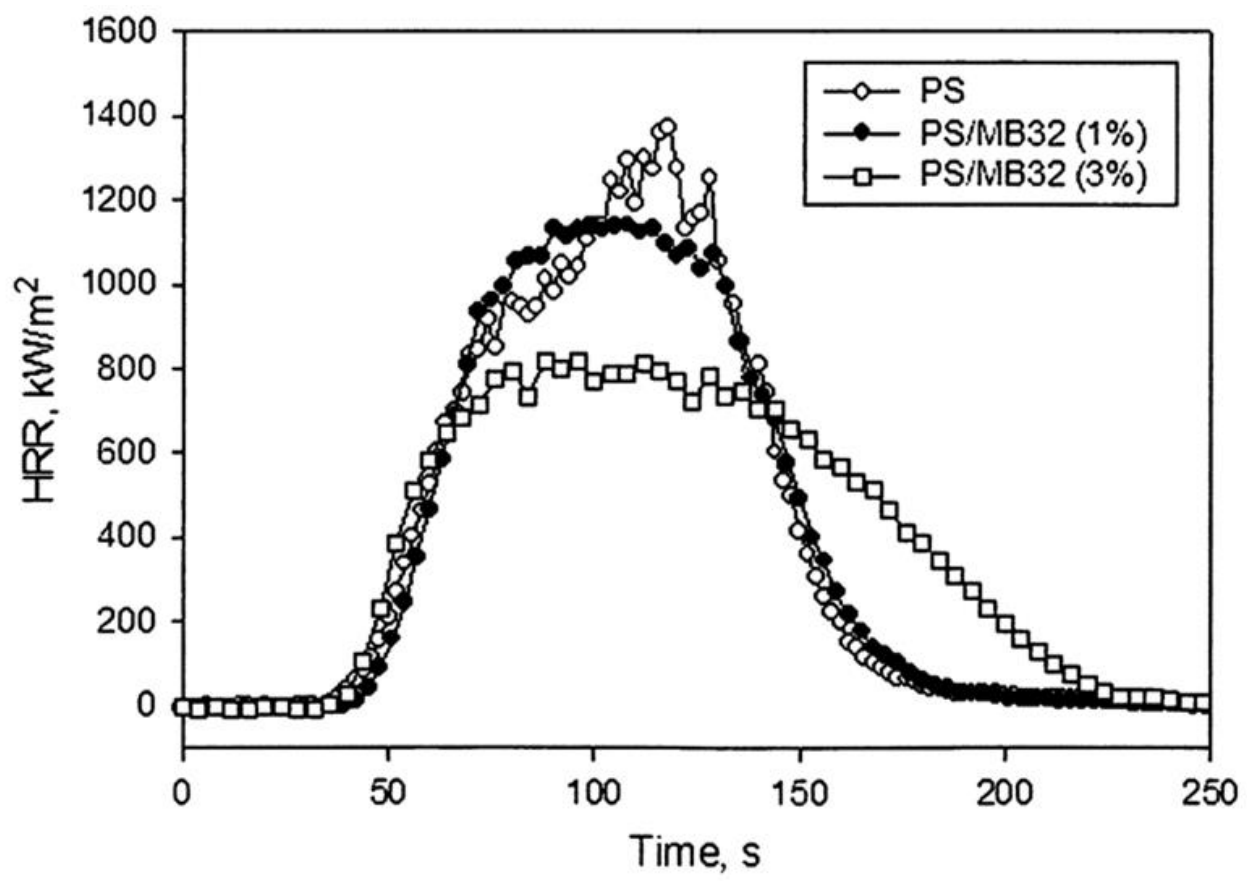

Fig. 17.: HRR plots for ABS and its nanocomposites.

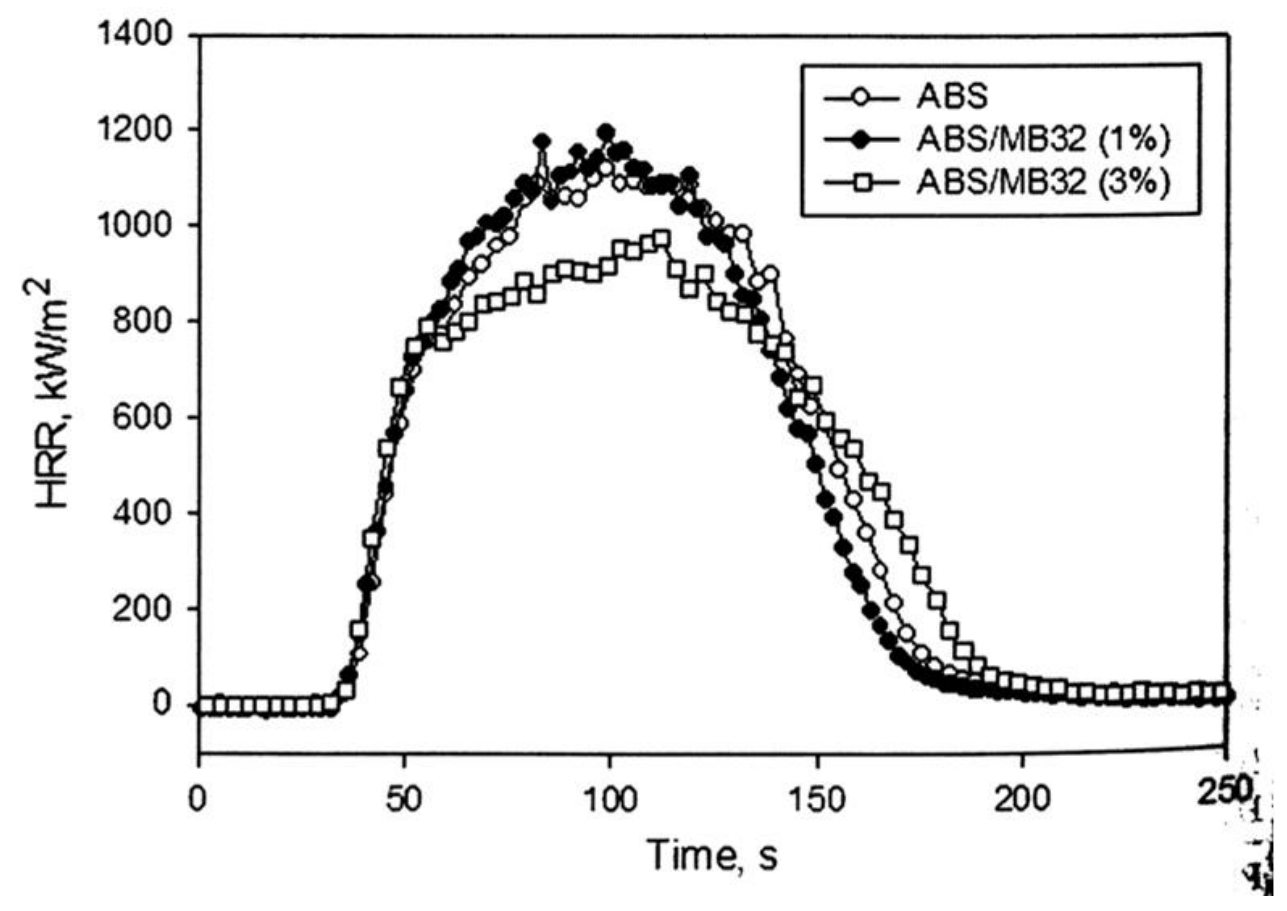

Polymer Degradation and Stability, Vol. 92, No. 10 (October 2007): pg. 1753-1762. DOI. This article is @ Elsevier and permission has been granted for this version to appear in e-Publications@Marquette. Elsevier does not grant permission for this article to be further copied/distributed or hosted elsewhere without the express permission from Elsevier. 
NOT THE PUBLISHED VERSION; this is the author's final, peer-reviewed manuscript. The published version may be accessed by following the link in the citation at the bottom of the page.

Fig. 18.: HRR plots for HIPS and its nanocomposites

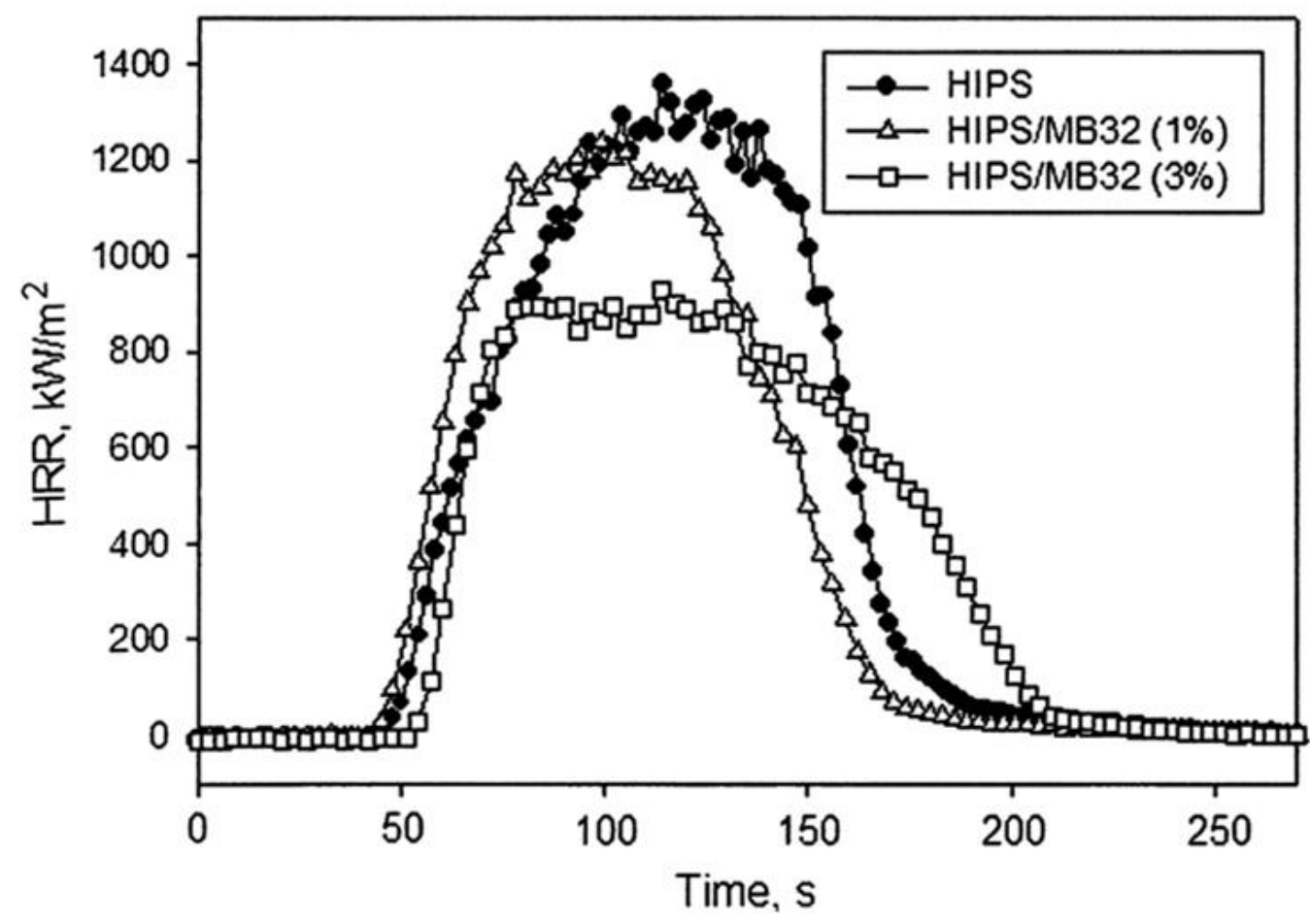

Fig. 19.: HRR plots for PS and its nanocomposites.

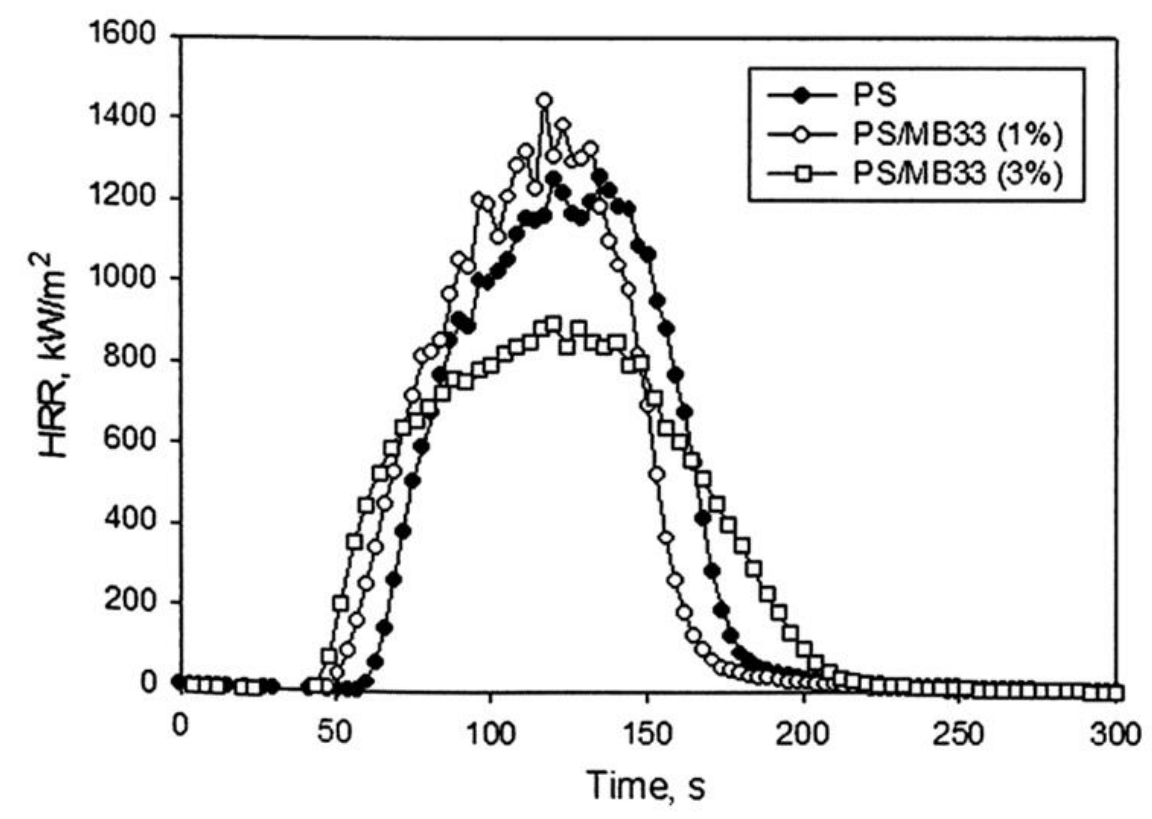

Polymer Degradation and Stability, Vol. 92, No. 10 (October 2007): pg. 1753-1762. DOI. This article is @ Elsevier and permission has been granted for this version to appear in e-Publications@Marquette. Elsevier does not grant permission for this article to be further copied/distributed or hosted elsewhere without the express permission from Elsevier. 
NOT THE PUBLISHED VERSION; this is the author's final, peer-reviewed manuscript. The published version may be accessed by following the link in the citation at the bottom of the page.

Fig. 20.: HRR plots for ABS and its nanocomposites.

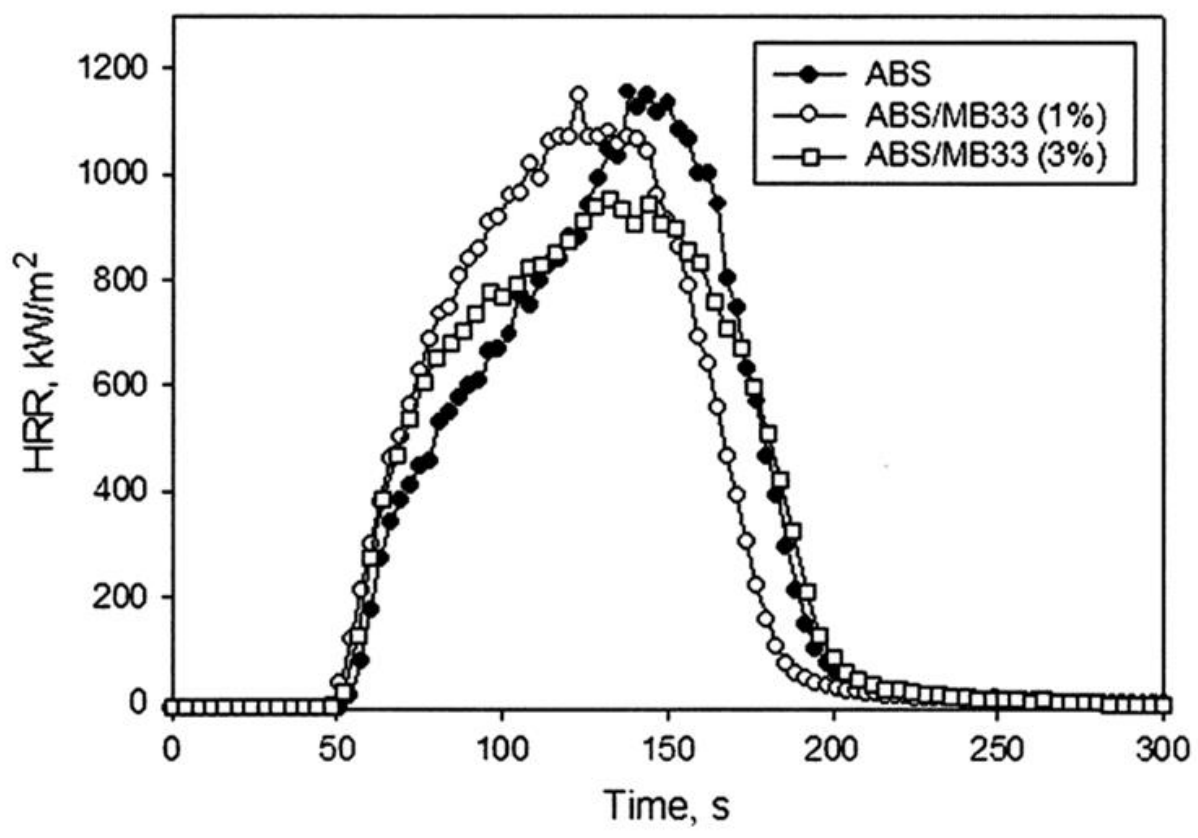

Fig. 21.: HRR plots for HIPS and its nanocomposites.

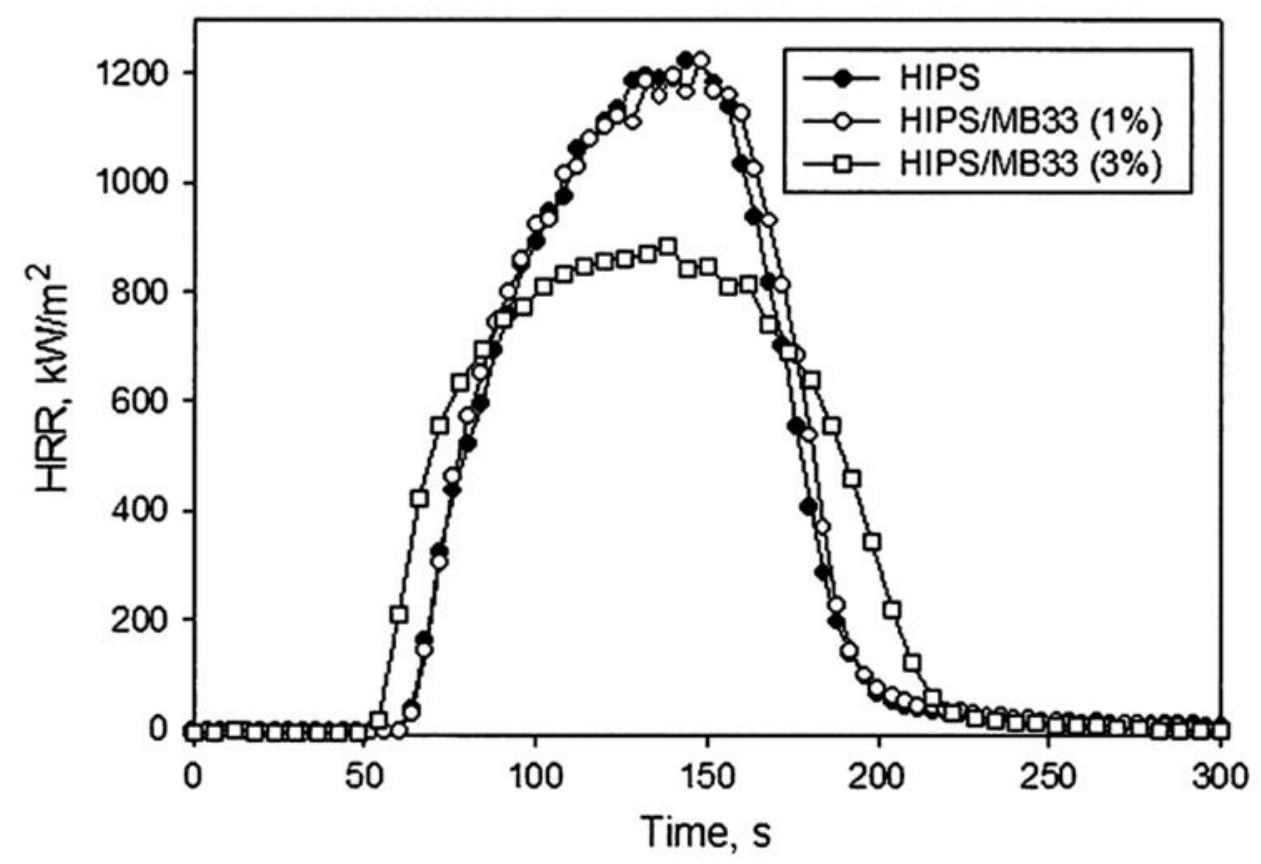

Polymer Degradation and Stability, Vol. 92, No. 10 (October 2007): pg. 1753-1762. DOI. This article is @ Elsevier and permission has been granted for this version to appear in e-Publications@Marquette. Elsevier does not grant permission for this article to be further copied/distributed or hosted elsewhere without the express permission from Elsevier. 